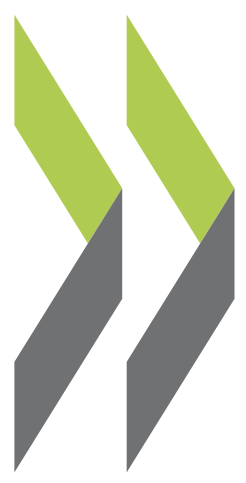

OECD Economics Department Working Papers No. 1273

\title{
Towards more gender equality in Austria
}

\section{Volker Ziemann}


Organisation de Coopération et de Développement Économiques

Organisation for Economic Co-operation and Development

03-Dec-2015

ECONOMICS DEPARTMENT

English - Or. English

TOWARDS MORE GENDER EQUALITY IN AUSTRIA

ECONOMICS DEPARTMENT WORKING PAPERS No. 1273

By Volker Ziemann

OECD Working Papers should not be reported as representing the official views of the OECD or of its member countries. The opinions expressed and arguments employed are those of the author(s)

Authorised for publication by Robert Ford, Deputy Director, Country Studies Branch, Economics Department.

All Economics Department Working Papers are available at www.oecd.org/eco/workingpapers

JT03387769

Complete document available on OLIS in its original format

This document and any map included herein are without prejudice to the status of or sovereignty over any territory, to the delimitation of international frontiers and boundaries and to the name of any territory, city or area. 
OECD Working Papers should not be reported as representing the official views of the OECD or of its member countries. The opinions expressed and arguments employed are those of the author(s).

Working Papers describe preliminary results or research in progress by the author(s) and are published to stimulate discussion on a broad range of issues on which the OECD works.

Comments on Working Papers are welcomed, and may be sent to OECD Economics Department, 2 rue André-Pascal, 75775 Paris Cedex 16, France, or by e-mail to eco.contact@oecd.org.

All Economics Department Working Papers are available at www.oecd.org/eco/workingpapers

This document and any map included herein are without prejudice to the status of or sovereignty over any territory, to the delimitation of international frontiers and boundaries and to the name of any territory, city or area.

The statistical data for Israel are supplied by and under the responsibility of the relevant Israeli authorities. The use of such data by the OECD is without prejudice to the status of the Golan Heights, East Jerusalem and Israeli settlements in the West Bank under the terms of international law.

\section{(C) OECD (2015)}

You can copy, download or print OECD content for your own use, and you can include excerpts from OECD publications, databases and multimedia products in your own documents, presentations, blogs, websites and teaching materials, provided that suitable acknowledgment of OECD as source and copyright owner is given. All requests for commercial use and translation rights should be submitted to rights@oecd.org 


\section{ABSTRACT/RESUME \\ TOWARDS MORE GENDER EQUALITY IN AUSTRIA}

There is ample empirical evidence for strong and persistent patterns of separated gender roles in Austria. While this model is generally considered to have worked well in the past, it faces important challenges arising from societal and economic changes in Austria. Hence, gender mainstreaming with the aim of more gender equality ranks high on the agenda of Austrian policy makers. An integrated policy framework to make Austria more gender-equal should build on 3 pillars: i) make the tax and benefit system more employment friendly ii) extend the care service infrastructure and iii) encourage more flexible workplace practices. Streamlining family policies across regions and levels of government would entail efficiency gains for all pillars. Long-run simulations suggest that achieving more gender equality in Austria could boost GDP by 13 percentage points until 2060. In addition, promoting more gender equality in the Austrian Society will improve Austrians' well-being.

Key words: gender equality, care infrastructure, family policies, Austria

JEL Classification: A14, C53, D6, H23, H5, I31, J13

\section{VERS PLUS D'ÉGALITÉ ENTRE LES SEXES EN AUTRICHE}

Il existe de nombreuses données empiriques prouvant qu'en Autriche, le modèle de répartition des rôles entre les hommes et les femmes est profondément enraciné, et qu'il persiste. Alors même qu'on considère généralement que ce modèle a bien fonctionné dans le passé, il est aujourd'hui remis en cause de manière importante par les évolutions sociétales et économiques en cours dans le pays. De ce fait, l'intégration systématique d'une démarche soucieuse de l'égalité entre les sexes visant à favoriser l'égalité hommes-femmes est l'une des priorités des responsables de l'action publique autrichiens. Un cadre d'action publique intégré au service d'une plus grande parité devrait s'articuler autour de trois axes principaux: i) rendre le système de prélèvements et de prestations plus favorable à l'emploi ; ii) développer les infrastructures d'accueil et de soins et iii) favoriser l'adoption de pratiques plus souples dans le monde du travail. Rationaliser les politiques familiales entre les différentes régions et les différents niveaux de l'administration entraînerait des gains d'efficience sous ces trois aspects. Les simulations à long terme montrent qu'une meilleure parité hommes-femmes permettrait à l'Autriche de gagner 13 points de PIB d'ici 2060. En outre, promouvoir l'égalité entre les sexes dans la société autrichienne améliorerait le bien-être de la population.

Mots-clés: égalité des sexes, infrastructure de santé et de garde d'enfants, politiques familiales, Autriche

Classification JEL: A14, C53, D6, H23, H5, I31, J13 


\section{TABLE OF CONTENTS}

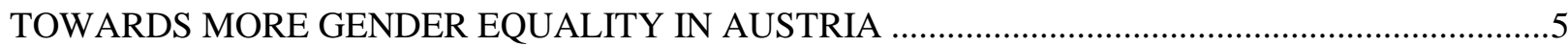

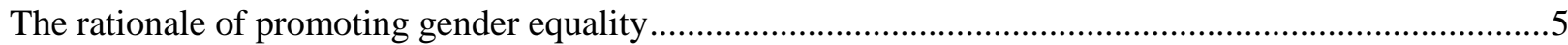

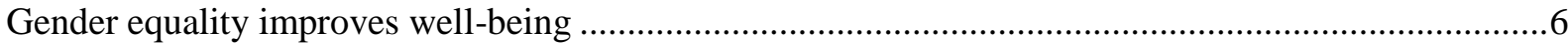

Macroeconomic implications of more gender-equal work-life arrangements.......................................

An integrated policy framework to promote gender equality in Austria ...............................................15

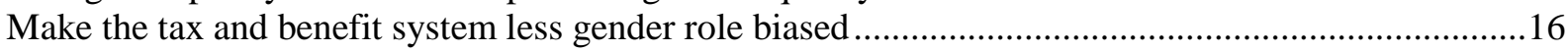

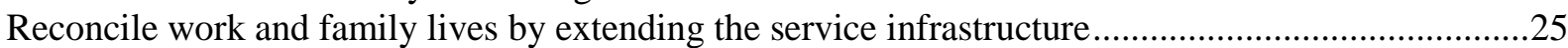

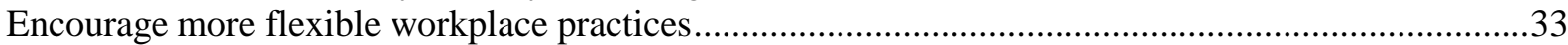

Streamline family policies across regions and levels of government....................................................36

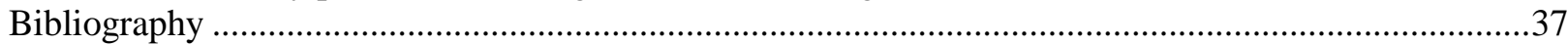

\section{Tables}

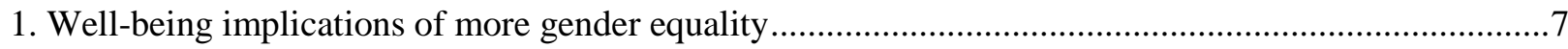

2. Fiscal costs of quantitative and qualitative childcare infrastructure improvements ............................13

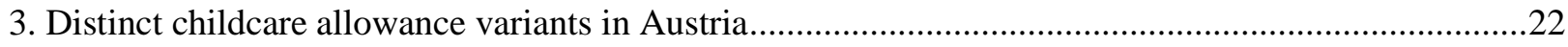

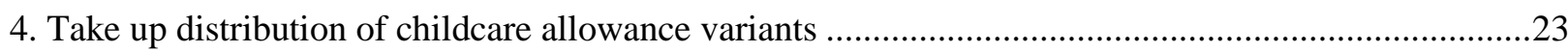

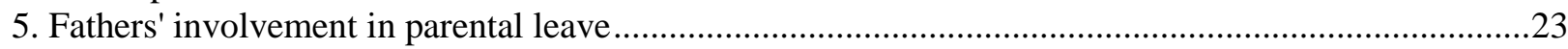

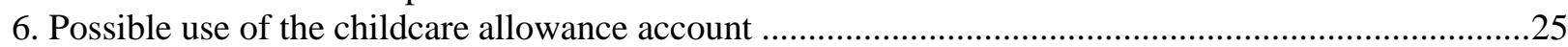

\section{Figures}

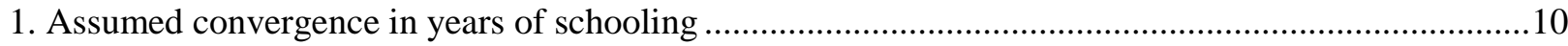

2. Human capital improvement induced by more gender equality .......................................................11

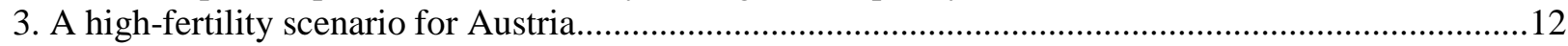

4. Trend productivity with respect to the baseline scenario ...................................................................14

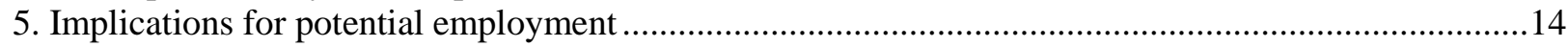

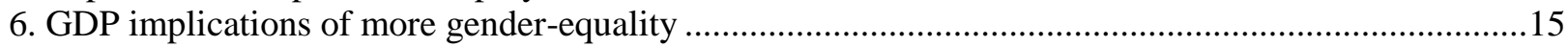

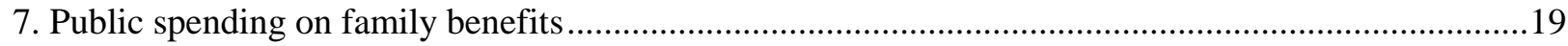

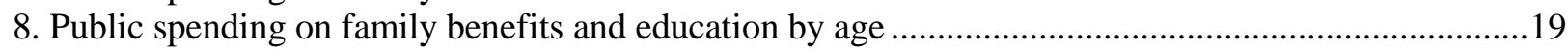

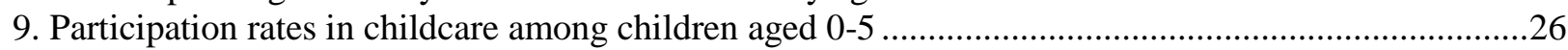

10. Participation of under 3 -year-olds in formal childcare services ...............................................27

11. Enrolment of children by type of care facility, age, region and degree of urbanisation .....................28

12. Net childcare costs for a sole-parent family with earnings of $50 \%$ of the average wage ..................29

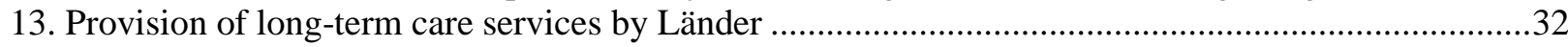

14. Number of beds in residential long-term care facilities ....................................................................33

\section{Boxes}

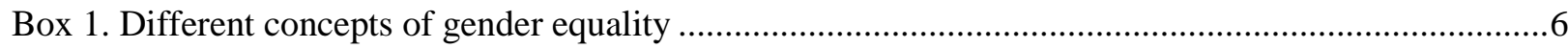

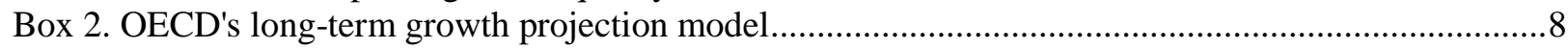

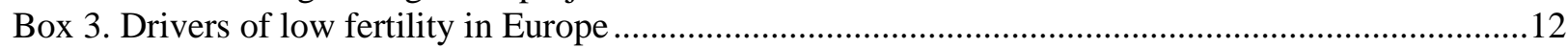

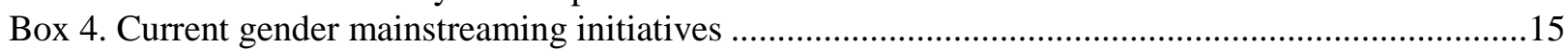

Box 5. Main features of Austria's personal income tax system ............................................................17

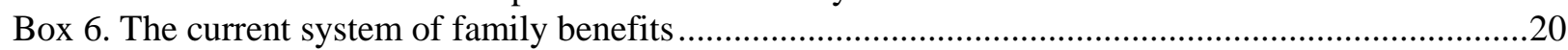

Box 7. Estimating the efficiency of support policies for working parents...........................................21

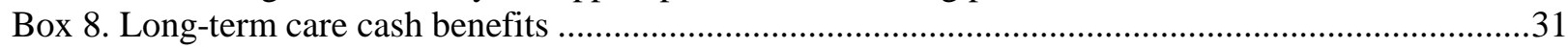

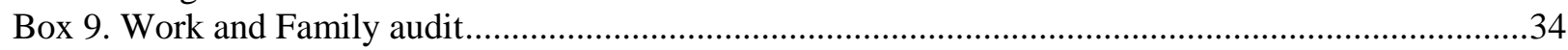

Box 10. "Die Freizeitoption" - a recent instrument to rebalance family and work life.............................35

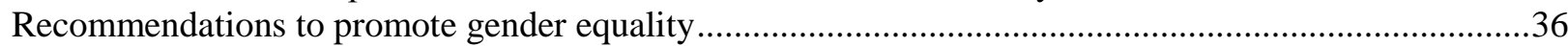


ECO/WKP(2015)91

\title{
TOWARDS MORE GENDER EQUALITY IN AUSTRIA
}

\author{
By Volker Ziemann ${ }^{1}$
}

\section{The rationale of promoting gender equality}

1. Despite important progress and increasing attention of policy makers, gender equality remains a largely unachieved goal, in Austria and elsewhere. Gönenç et al. (2015) provides evidence on the prevailing family patterns that involve separate and asymmetric gender roles in Austria. Aspirations for more gender equality call for change. It is by now widely accepted that gender equality requires more than equal opportunities and equal access to institutions. Women also need the decisional autonomy to develop the capabilities to make use of equal opportunities and live up to their aspirations. Therefore, achieving gender equality requires a flexible approach with a dedicated mix of objectives that eliminate barriers to equal opportunities and objectives that prescribe equal outcome targets for women and men (Box 1).

2. Many Austrian women with family tasks, notably child care, work part-time. The vast majority of them declare doing so voluntarily, but there is a common perception, as in other OECD countries with a similar experience (e.g. Germany and Switzerland) that if conditions were more conducive for full-time work, a significant proportion of women would shift from part-time to full-time employment to improve earnings and careers. Entrenched social norms and prevalence of stereotypes often implicitly reduce the set of opportunities that are effectively available to women (Box 1) which may bias their perception. For instance, Nordenmark (2013) shows that women who live in an egalitarian gender regime (e.g. Sweden, Denmark, Norway) more often report disagreement about the division of household work and work-family conflicts than women who live in traditional gender regimes, in particular in Austria and Switzerland. Against this background, the provision of equal opportunities in a legalistic sense may not be sufficient to achieve gender equality as women's access is limited de facto. One example is the option for parents to work part-time until the child's $7^{\text {th }}$ birthday. While this option addresses both fathers and mothers, it is mostly taken up by women (Gönenç et al., 2015).

3. But even if individual choices are made under autonomy and with an equal set of opportunities, they may still give rise to suboptimal outcomes, individually and collectively. For instance, while reduced working time may be individually preferable, myopic behaviour may not fully internalise long-term effects on pension entitlements and risk of old-age poverty. Collectively, the decision to work less also affects the viability of social security institutions owing to reduced contributions and lower growth potential. The inadequate use of human capital represents a cost to the family through lower income but also exerts a negative externality on society as a whole. A second example of an adverse externality is low fertility. It undermines growth potential and jeopardises the intergenerational balance underlying social institutions through increasing dependency ratios. While child bearing is a profoundly intimate matter and choice, raising the awareness of negative spill-overs and fostering a more child-friendly environment can be seen as a part of public policy so as to internalise negative externalities of individual choices and correct for market failures.

1. The author is a member of the OECD Economics Department. He would like to thank Willem Adema Philip Bagnoli, Carlotta Balestra, Robert Ford, Isabelle Hassler, Vincent Koen, Mathilde Mesnard, Sandra Müllbacher, Ali Nabil, Alvaro Pereira, Monika Queisser, Pia Rattenhuber, Karin Rysavy, Olivier Thevenon, Andreas Wörgötter and participants of a dedicated brownbag seminar at the OECD for their valuable comments, suggestions and data provision. Special thanks are due to Rauf Gönenç for his guidance and inspiration, as well as to Beatrice Guerard and Heloise Wickramanayake for excellent editorial assistance. This Working Paper was published as Chapter 2 of the OECD's 2015 Economic Survey of Austria. 


\section{Box 1. Different concepts of gender equality}

\section{Equality of outcomes}

Equality of outcomes seeks identical outcomes in terms of societal and economic indicators such as income, wealth or other well-being aspects. The major caveat is that the concept denies differences in individual preferences, choice and efforts (Phillips, 2006). Further, delivering equality in one measure does necessarily create inequalities in other measures as the individual preferences differ (e.g. with respect to income and leisure). On the other hand, affirmative action by imposing gender quotas in the labour market can entail greater efforts of firms to identify qualified women (Holzer and Neumark, 2000) and can encourage more women to participate in the competition for jobs (Niederle et al., 2013).

\section{Equality of opportunity}

Equality of opportunity acknowledges the freedom of personal choice and differences in preferences. It distinguishes between "legitimate" differences in outcomes due to different choices made and "illegitimate" differences in outcomes that arise from discrimination or other impediments beyond one's control (Robeyns, 2006). The pursuit of equality of opportunities between the genders means to strive for equal access to education, health and the labour market, and, in a nutshell, the elimination of any barriers that may hamper men and women to realise their individual aspirations. Similar to the goal of equality of outcomes, it also requires a certain amount of redistribution in order to neutralise the inequitable distribution of initial resources. The major caveat of the concept of equal opportunities is the fine line that it draws between the inequality the agent should be accountable for and the inequality that results from exogenous factors, in particular as individual choices are influenced by social norms, cultural perceptions, habits and asymmetric information.

\section{Equality of autonomy}

It is by now widely accepted that gender equality requires more than equal opportunities (Seguino, 2013). In his seminal work on the aspects of freedom, Amartya Sen (1993) extents the concept of equal opportunities by distinguishing between the opportunity aspect of freedom and the process aspect of freedom. Its combination is referred to as equality of autonomy and can be described as not only having a sufficiently large set of opportunities available but also benefiting from decisional autonomy in choosing among them and immunity from interference by others. To this extent, a redistribution of resources or incentivising certain outcomes can be warranted to level the playing field and to allow all agents to acquire equal capabilities and have equal access to resources. As such, promoting equality of autonomy can be seen as a hybrid between the goal of equality of outcomes and the goal of equality of opportunities. The balance between the two latter concepts depends on the domain and the extent of biases inherent in values and preferences. For instance, it is reasonable to pursue equality of outcomes when focusing on the health status of individuals. On the contrary, educational choices may be better targeted through equality of opportunities, subject to the impacts of gender socialisation (e.g. prevalent stereotypes) that may require pro-active action to neutralise its biases.

\section{Gender equality improves well-being}

4. Pursuing the goal of gender equality is an aim in itself. But it is also likely to generate improvements across a wide range of well-being dimensions. Summarises the tentative impacts of a more gender-equal Austrian society on the various dimensions of well-being and suggests corresponding channels. Modifications to early life education, including gender-sensitive curricula and better guidance throughout the schooling period, may break down cultural and traditional barriers that have so far restricted intergenerational educational mobility (Scheebaum et al., 2013 and OECD, 2014a). In particular girls and children with an immigrant background are likely to benefit from the greater set of opportunities that opening up of the educational system would provide. More diversification in the choices of fields of study would enlarge the set of opportunities for both genders and facilitate better matches between talent and skill formation (Musset et al., 2013). Beyond school, better work-life balances would allow more women to enrol in on-the-job training and professional courses. 
ECO/WKP(2015)91

Table 1. Well-being implications of more gender equality

\begin{tabular}{|c|c|c|}
\hline Well-being dimensions & Outcomes & Channels \\
\hline \multirow{3}{*}{ Education and skills } & Increase in educational attainment & Open up educational tracks \\
\hline & Improvement in intergenerational mobility & Open up educational tracks \\
\hline & $\begin{array}{l}\text { Better preservation and more } \\
\text { diversification of skills }\end{array}$ & $\begin{array}{l}\text { More post-formal education and on-the-job } \\
\text { training for women }\end{array}$ \\
\hline \multirow{4}{*}{ Jobs and earnings } & Reduction of the gender pay gap & $\begin{array}{l}\text { Reduction in structural asymmetries in the } \\
\text { labour market }\end{array}$ \\
\hline & More innovations & $\begin{array}{l}\text { More gender diversity in managerial and } \\
\text { entrepreneurial positions }\end{array}$ \\
\hline & Creation of personal service sector jobs & Market supply of household services \\
\hline & $\begin{array}{l}\text { New work organisation challenges in } \\
\text { enterprises. }\end{array}$ & Reduction in hours worked by men \\
\hline \multirow{2}{*}{ Income and wealth } & Increase in family income & $\begin{array}{l}\text { Stronger and more ambitious involvement of } \\
\text { women in the labour market }\end{array}$ \\
\hline & More financial independence for women & $\begin{array}{l}\text { Higher earnings for women and a more even } \\
\text { distribution of wealth }\end{array}$ \\
\hline \multirow[t]{2}{*}{ Health } & Impact on women's health uncertain & $\begin{array}{l}\text { Additional risks of stress for women, but also } \\
\text { relief from care duties and less mental } \\
\text { retirement }\end{array}$ \\
\hline & Improvement in men's health & $\begin{array}{l}\text { Fewer working hours for men and more time } \\
\text { spent with the family }\end{array}$ \\
\hline \multirow{3}{*}{ Work-life balance } & Better work-life balance for both genders & $\begin{array}{l}\text { Convergence in time spent on paid and } \\
\text { unpaid work between genders }\end{array}$ \\
\hline & Reduced strains at work and at home & $\begin{array}{l}\text { Family-friendly work organisation and more } \\
\text { formal childcare }\end{array}$ \\
\hline & $\begin{array}{l}\text { Improved child well-being, notably in } \\
\text { vulnerable families }\end{array}$ & $\begin{array}{l}\text { Stronger presence of father and better } \\
\text { socialisation through kindergarten access }\end{array}$ \\
\hline \multirow[t]{2}{*}{ Life satisfaction } & Realisation of broader life choices & $\begin{array}{l}\text { Broader options for economic participation, } \\
\text { earnings and family organisation }\end{array}$ \\
\hline & Realisation of initial child rearing desires & $\begin{array}{l}\text { Better reconciliation of child raising and } \\
\text { professional aspirations }\end{array}$ \\
\hline
\end{tabular}

5. A better reconciliation of work and family life would enable parents to maintain or increase their employment commitment and have the number of children they would like to at the time of their choosing. Women could better pursue their individual and professional aspirations. Improved job satisfaction exerts a protective role on physical health and shields against mental disorder (Barnay, 2014). In addition, women would be less restrained by caregiving activities which are found to induce psychological stress, strain and overall health deterioration. Recent evidence suggests that the prevalence of mental health problems is $20 \%$ higher among carers than among non-carers (OECD, 2011b). Moreover, Adema et al. (2014) suggest that enrolment in formal Early Childhood Education and Care (ECEC) facilities has a negative effect on infant mortality rates, possibly related to the fact that such environments help to identify health issues at an earlier stage. Formal childcare is also shown to be positively associated with the child's cognitive development, in particular for children in disadvantaged households (Huerta et al., 2011). At the same time, very early enrolment outside home (before 6 months) impedes the opportunity of extended breastfeeding and deprives the child of the continuity in infant care and attention which may have adverse effects on its emotional well-being (OECD, 2011c).

6. From the employer's perspective, committed male and female workers that can remain in the workforce makes them regardless of gender - and this is key to avoiding discrimination - equally attractive and deserving of investment in their training and career development, which enables men and women to pursue careers. A greater use of flexible work and leave arrangements by both genders would make parental leave periods less penalising. A convergence in hours worked between women and men and more ambitious career trajectories for women would further reduce the gap in take-home pay. Stronger female labour participation, in particular in full-time jobs, increases family income and improves career prospects 
for women. Higher income for women fosters their financial independence, reduces individual, family and child poverty risks, improves resilience against adverse financial shocks and increases retirement entitlements and wealth. Financial independence gains more and more importance owing to rising numbers for one-person and single-parent households. ${ }^{2}$

\section{Macroeconomic implications of more gender-equal work-life arrangements}

7. This section uses the OECD's in-house growth model (Johansson et al., 2013) to offer long-term simulations of alternative family and work arrangements in Austria. The model is based on a growth accounting framework that allows for adjustments in structural parameters that reflect changes in the worklife balance between women and men, namely the transition towards a more balanced dual-earner dualcarer model (Box 2).

\section{Box 2. OECD's long-term growth projection model}

The model provides a projection of potential output and is based on the supply-side of the economy. The different long-term growth determinants (physical capital $(K)$, human capital $(H)$, potential employment $(N)$, labour efficiency $(E)$ ) are aggregated trough a standard Cobb-Douglas production function with constant returns to scale:

$$
y=\alpha(n+e+h)+(1-\alpha) k
$$

where lower case letters denote natural logarithms and a the wage share. Each component is projected out to 2060 according to long-term dynamics and convergence patterns between the countries. Changes to per capita GDP can be decomposed into changes trend productivity and changes in labour utilisation:

$$
\Delta(y-p)=\Delta(y-n)+\Delta(n-p)
$$

where $\mathrm{P}$ denotes the total population based on Eurostat (for European countries) and UN (for non-European countries) projections. By rearranging (1), three drivers of changes in trend productivity can be distinguished:

$$
\Delta(\mathrm{y}-\mathrm{n})=\Delta \mathrm{e}+\Delta \mathrm{h}+\{(1-\mathrm{\alpha}) / \mathrm{\alpha}\} \Delta(\mathrm{k}-\mathrm{y})
$$

- Labour efficiency $(\Delta e)$ is projected based on convergence towards the technological frontier. Speed of convergence depends on the initial position and structural factors such as product market regulation.

- Human capital $(\Delta \mathrm{h})$ is a function of average years of schooling with decreasing rates of return. The baseline specification assumes that these returns to education are the same for all countries and that educational attainment (measured by average years of schooling) of the $25-29$ age cohorts improves by $1 \%$ per year over the projection horizon.

- Physical capital intensity $(\Delta(\mathrm{k}-\mathrm{y}))$ is affected by changes in interest rates and has a mean-reverting component so that the capital-output ratio $(\mathrm{K} / \mathrm{Y})$ stabilises over the long run.

Labour utilisation can be rewritten using labour force (LF) and working age population (PWA), the latter being defined as the population aged 15 years and older. This decomposition reveals three drivers for changes in labour utilisation:

(4)

$$
\Delta(\mathrm{n}-\mathrm{p})=\Delta(\mathrm{n}-\mathrm{ff})+\Delta(\mathrm{ff}-\mathrm{pwa})+\Delta(\mathrm{pwa}-\mathrm{p})
$$

- Structural unemployment $(\Delta(\mathrm{n}-\mathrm{If}))$ is assumed to converge to its lowest level observed between 2007 and 2014.

- Labour force participation ( $\Delta($ (ff-pwa) $)$ is projected based on a cohort model. Participation rates of older workers are adjusted in line with implemented pension reforms. In addition, future increases in the pensionable age are assumed by indexing it to projected life expectancy.

- Active population ratio ( $\Delta($ pwa-p)) follows directly from the population projection and is affected by underlying assumptions concerning fertility, mortality, net immigration and life expectancy.

2. OECD (2011a) projects an increase of $29 \%$ for the former and $10 \%$ of the latter in Austria from the earlymid-2000s to 2025-30. 
ECO/WKP(2015)91

\section{Labour force participation and labour intensity}

8. Thevenon (2013) studies the impact of policies and institutions on female labour participation, distinguishing between full-time and part-time participation. Results suggest that full-time employment of women is likely to benefit most from spending on leave and birth grants, spending on childcare services in general and an the increase in the coverage of formal childcare facilities for children aged 0-2 years in particular. He also argues that an estimation of individual effects of the aforementioned institutional and policy features, including the tax and benefit system, care infrastructure and an enabling work organisation, is difficult due to the likely interaction of these features. For instance, the impact of an extension of the maternal or parental leave systems depends on the availability of formal childcare facilities and familyfriendly workplace practices. Thevenon (2013) recognises that the evaluation of the impact of individual policies is burdensome and, given the low degrees of freedom resulting from multiple interactions, econometrically questionable.

9. The present simulation approach is based on a convergence of part-time patterns and participation in Austria towards those observed on average in selected countries ${ }^{3}$. Currently, the incidence of part-time among Austrian women is 5 times higher than the incidence of part-time among Austrian men. In the more gender-equal scenario it is assumed that this ratio convergence towards the OECD and peer country average of 3 until 2025. While participation rates for men (81\%) are close to those observed in peer countries, female participation (71\%) still lags behind rates observed in the selected countries (75\%). On the other hand, men engaged in full-time work spend considerably more time at work with respect counterparts in peer countries (43.5 hours per week against 41.8). Accordingly, the more gender-equal scenario assumes the following convergences to take place between 2016 and 2025:

- Increase in female labour participation rate from $71 \%$ to $75 \%$.

- Reduction in the incidence of female part-time work from $33 \%{ }^{4}$ to $21 \%$.

- A reduction in hours worked per week for full-time working men from 43.5 to 41.8 .

All other things equal, these effects would increase total hours worked by $3.5 \%$ by 2025 . Convergence is assumed to be linear which translates into annual increases in total hours worked of $0.35 \%$ per year from 2016 to 2025 with respect to the baseline scenario. In terms of the growth accounting framework (Box 2), increases in hours worked per person translate one-to-one into increases in labour efficiency $(\Delta \mathrm{e})$ while increase in female labour participation increase labour utilisation $(\Delta(\mathrm{n}-\mathrm{p}))$.

\section{Human capital}

10. More gender equality would also lead to more diversified choices of fields of study across genders. Enrolment and duration in higher education are likely to increase and pave the way for a higher accumulation of human capital. In the OECD growth modelling framework (see Box 2), human capital is indeed measured as a function of average years of schooling with a decreasing rate of return. Currently, Austria lacks behind comparable countries. The more gender-equal scenario assumes that the average number of years in schooling will converge towards the one observed in Denmark by 2060 (Figure 1).

3. Selected countries are Northern European Countries and France. This group of countries seems to offer better work-life balances as evidenced by stronger female labour participation combined with higher fertility rates.

4. The common OECD definition based on a 30-usual-hour cut-off in the main job is used. National definitions vary considerably and are therefore not adequate for comparisons and convergence assumptions. 
Figure 1. Assumed convergence in years of schooling

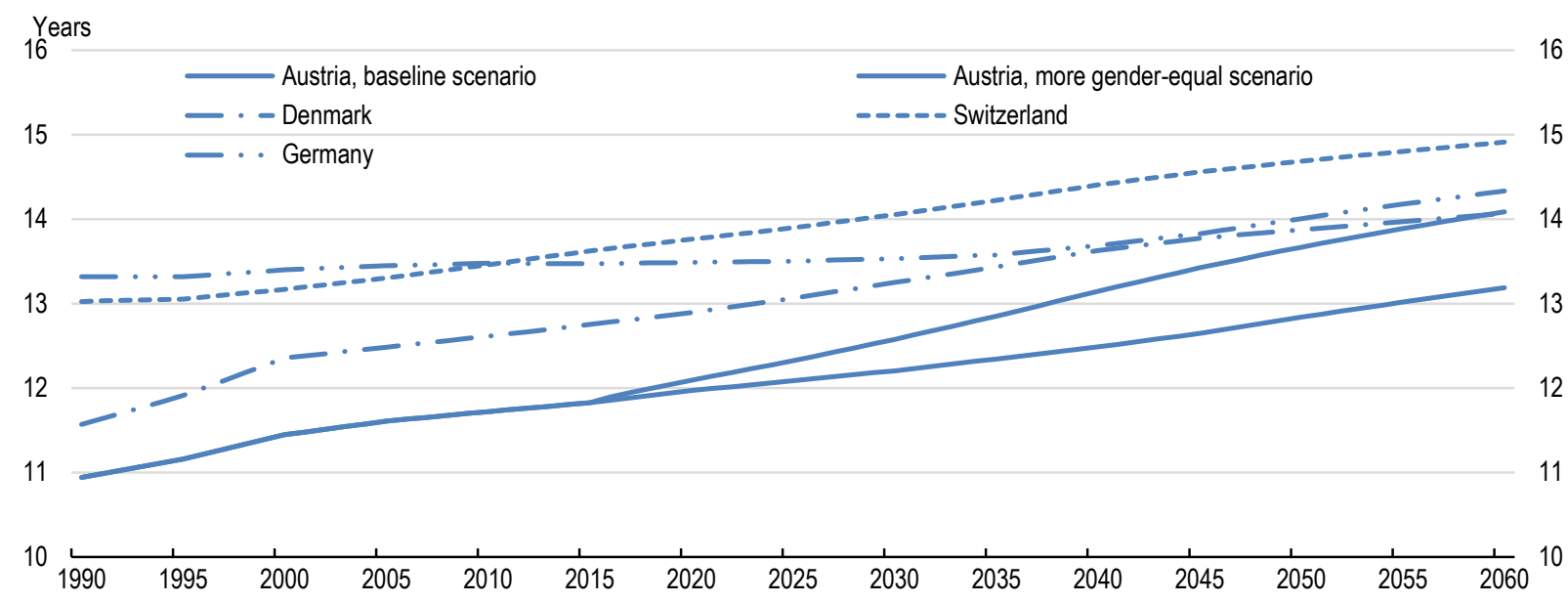

Source: OECD projections and calculations based on OECD Economic Outlook.

11. The modelling framework assumes that the return to schooling has the same functional form for all countries and across scenarios. As a result, some potentially positive effects on human capital of a more gender-equal society cannot be captured. For instance, a better transition from school/university to work and a reduction in the incidence of part-time work is likely to increase human capital and reduce hysteresis effects. Indeed, full-time work coincides with more on-the-job-training, higher participation in regular professional education and training courses as well as better job opportunities and careers. Additionally, a more gender-equal work environment would reduce the incidence of over-qualification and over-skilling. Mussat et al. (2013) revealed that Austria exhibits the highest incidence of over-skilled workers across OECD countries and over-skilling is particularly high for Austrian women ${ }^{5}$. Especially the use of information-processing skills is strongly gender-biased. The incidence of under-exploiting skills at work is particularly high among part-time employees which may be one explanation for the fulltime dividend that contributes to the gender pay gap. Better matches would further increase the return to education. ${ }^{6}$ The simulated effect of less segregated educational and job-market patterns for human capital (Figure 2) can therefore be seen as a lower boundary for the expected total effect.

5. Adalet and Andrews (2015) suggest that Austria could increase its labour productivity by $6 \%$ by reducing the skill mismatch to best practices, observed in countries such as Sweden.

6. The modelling framework offers potentially two ways of introducing a positive human capital effect in the simulation. The direct approach would be to expand the return to schooling equation by introducing indicators for the incidence of part-time, over-qualification and youth unemployment. Compared to the current equation that derives human capital solely from years of schooling, these parameters would capture the effectiveness of the transition between school and work, and hence serve as a proxy for the mis-use or the destruction of human capital. The second, an indirect method would be to assume that the distance to the labour efficiency frontier is to some extent driven by the way a country makes use of and preserves its initial human capital. As such, the dual-earner model would result in a faster convergence to the frontier as compared to the status quo. 
ECO/WKP(2015)91

Figure 2. Human capital improvement induced by more gender equality

Percentage point increase in human capital from the baseline scenario to the more gender-equal scenario

7

6

5

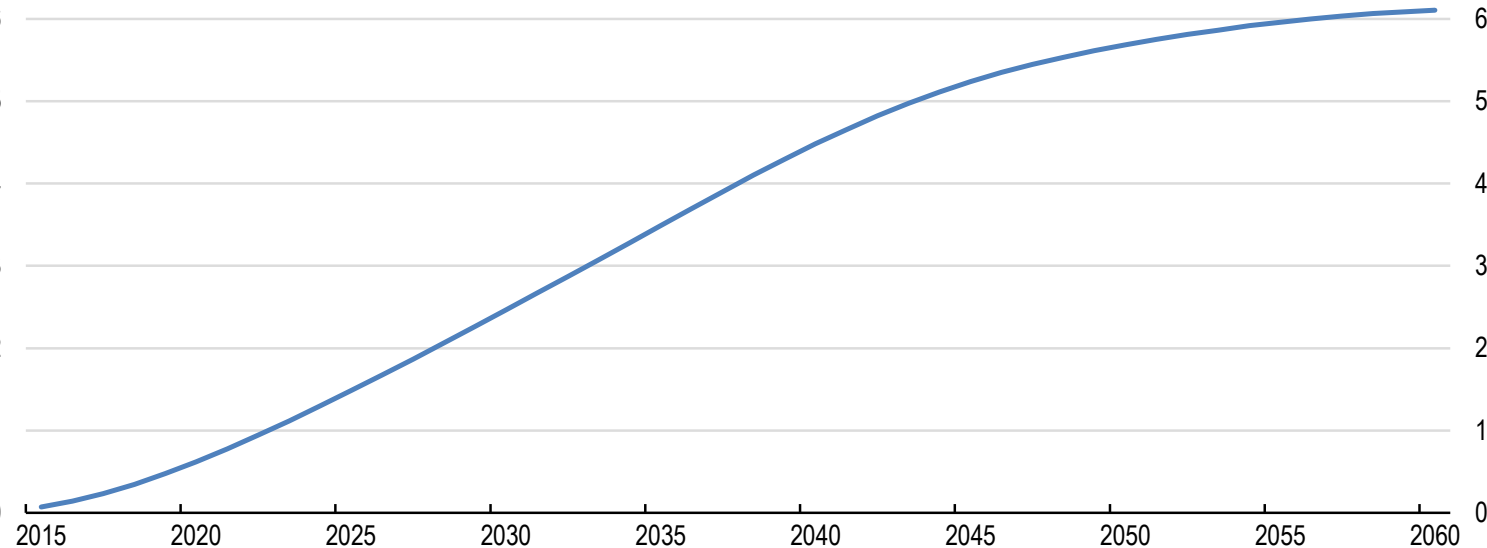

Source: OECD calculations.

\section{Fertility}

12. A recent study based on long-term time trends (Adema et al., 2014) identifies fertility as one of the three main indicators of family and child well-being, the others being female employment and infant mortality. According to the authors, cross-country differences in total fertility rates reflect, at least to some extent, difficulties in combining work and family commitments. The lack of adequate formal childcare and enabling workplaces makes it difficult to reconcile family and career aspiration for women. As a result, many couples have fewer children than intended and are pushed to abandon or postpone parenthood (Adema, 2012).

13. While the decision to have a child is an entirely private one, a more gender-equal society is likely to increase child bearing for several reasons. First, an enabling infrastructure, namely full-day early childhood care and family-friendly workplaces, mitigate the tension between work and family life and break with the current practice of having to choose between the two (Box 3). Ideally, the birth of a child would not interfere with medium- and long-term career plans of women, which facilitates the decision to have children. Second, a higher prevalence of dual-earner families increases average family income, makes child bearing financially more affordable and reduces the likelihood of child poverty. Third, a more balanced distribution of unpaid work at home ensures an equal sharing of the burden of child care tasks (Huerta et al., 2013). Sullivan et al. (2014) argue that the recent upturn in fertility rates in some lowfertility countries coincides with an increase in the contribution of fathers, in particular younger and highly educated fathers, to childcare and domestic tasks. De Laat and Sevilla-Sanz (2011) find evidence that men's involvement in home production explains the positive cross-country correlation between female labour participation and fertility. Similarly, Buber-Ennser et al. (2014) finds a strong positive correlation between a mother's satisfaction with the division of childcare tasks and her intention of bearing a second child. 


\section{Box 3. Drivers of low fertility in Europe}

Several researchers have stressed the importance of welfare state regimes for family and fertility outcomes. Neyer (2013) identifies "commodification", "de-familialisation" and "de-gendering of employment and care" as the main welfare-state principles that shape fertility patterns across Europe. These three principles materialise in policies that i) allow to form and maintain a household and a family; ii) deliver an enabling set of opportunities and the capability to choose and iii) ensure fairness in the gender distribution of family work and care. Opponents to this view often claim that fertility is more likely to be driven by social norms than by family policies (e.g. Sobotka and Testa, 2008). Klüsener et al. (2013) find evidence for a disconnection between inherited social norms and family policies with respect to fertility. They compare fertility rates in a German-speaking community in Belgium, close to the German border, with fertility rates in the rest of Belgium and Western Germany. This community shares social norms with Western Germany and the family policy framework with the rest of Belgium. The results show that the community's fertility pattern is much closer to the one observed in the rest of Belgium than to the one of Western Germany which suggests that family policies settings prevail over social norms. Again, the striking difference between the 2 countries in terms of family policy resides in the coverage of external early childhood care and preschool facilities. The provision of external child care indeed perfectly illustrates the extent to which public policy can be constraining or enabling for the child-raising process. Lesthaeghe and Permanyer (2014) identify two distinct low fertility clusters In Europe. On the one hand, Southern European countries that face matching problems on the partnership market, leading to "pronounced partnership and parenthood postponement"? On the other hand, German-speaking countries fail to allow parents to reconcile work and family which delays or even hinders the formation of a family. The insufficiently developed care infrastructure is put forward as the main obstacle in these countries.

14. Eurostat population projections provide both a baseline and a low-fertility scenario. By extrapolating the differences for each age cohort, a high-fertility scenario is obtained for Austria. It entails a gradual increase in the average fertility rate from 1.45 births per woman in 2013 to 1.9 in 2060, against 1.6 in the baseline and 1.3 in the low-fertility scenario. Figure 3 illustrates the changes with respect to the baseline for the total population and the working age population.

\section{Figure 3. A high-fertility scenario for Austria}

\section{Percentage point increase from the baseline scenario to the more gender-equal scenario}

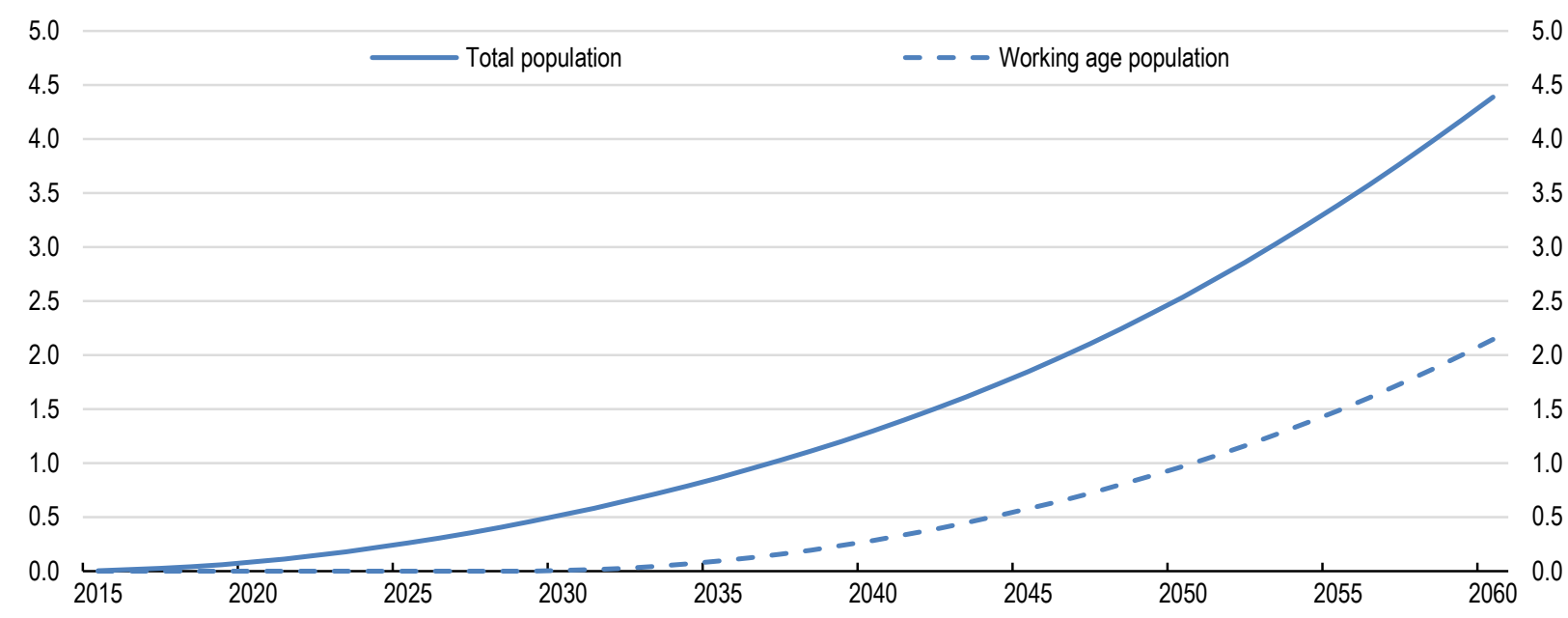

Source: Eurostat population projections and OECD calculations

\section{Public investment and government spending}

15. A necessary condition for the transition towards a more balanced dual-earner dual-carer model and greater employment participation of sole parents is better access to quality early childhood education and care facilities. The Austrian Federal Chamber of Labour (2013) estimates a gap of 35000 places in 
care facilities for children aged 0-2 years (day-care centres). Filling this gap would lift the enrolment rate for $0-2$ years above the Barcelona target of 33\%. The construction of the missing places is projected to cost about EUR 100 million per year over 3 years. In addition, an improvement in the quality of childcare is modelled via the reduction of the child-teacher ratio and a general increase in opening hours. This would lift share of full-day care centres from currently $44 \%$ to close to $70 \%$ over the next 3 years. Total additional personnel costs are assumed to amount to EUR 200 million in the first year, EUR 350 in the second and EUR 500 million in the third year increasing with inflation and productivity thereafter. Table 2 summarises the derived fiscal implications for the more gender-equal scenario.

Table 2. Fiscal costs of quantitative and qualitative childcare infrastructure improvements

\begin{tabular}{|c|c|c|c|c|c|c|c|c|c|c|c|}
\hline & & & 2018 & 2016 & & 2018 & $\begin{array}{l}2019- \\
2060\end{array}$ & 2016 & 2017 & 2018 & $\begin{array}{l}2019- \\
2060\end{array}$ \\
\hline & \multicolumn{3}{|c|}{ Euros in million } & \multicolumn{4}{|c|}{$\%$ of component } & \multicolumn{4}{|c|}{$\%$ of GDP } \\
\hline Government investment & 100 & 100 & 100 & 1.05 & 1.05 & 1.05 & 0.00 & 0.03 & 0.03 & 0.03 & 0.00 \\
\hline Government current disbursements & 200 & 350 & 500 & 0.13 & 0.22 & 0.31 & 0.31 & 0.06 & 0.11 & 0.16 & 0.16 \\
\hline Government total disbursements & 300 & 450 & 600 & 0.19 & 0.28 & 0.38 & 0.31 & 0.09 & 0.14 & 0.19 & 0.16 \\
\hline
\end{tabular}

Source: OECD calculations inspired by numbers provided by the Austrian Federal Chamber of Labour.

16. These numbers are considerably larger than the investment that is currently envisaged. Government expenditures do not directly enter the growth accounting framework, which is based on supply-side components (see Box 2). It is implicitly assumed that the debt-to-GDP ratio converges to $60 \%$ with a maximum fiscal consolidation effort of $1 / 2$ percentage point of GDP per year. In absence of offsetting effects from spending cuts or additional revenues, increases in government spending therefore imply a longer period of fiscal consolidation with respect to the baseline. In their assessment, The Austrian Federal Chamber of Labour (2013) assumes that the mere increase in female labour participation auto-finances the investment projects within an estimated time of 7 years (average of the 2 scenarios presented).

\section{Potential output}

17. Trend productivity is affected by increases in labour efficiency due to higher hours worked per person and by increases in human capital. Taken together, trend productivity is projected to increase by close to $10 \%$ until 2060 of which $3.5 \%$ result from gains in labour efficiencies (see above) and a little more than $6 \%$ from gains in human capital (Figure 4). 
Figure 4. Trend productivity with respect to the baseline scenario

Percentage point increase in trend productivity from the baseline scenario to the more gender-equal scenario

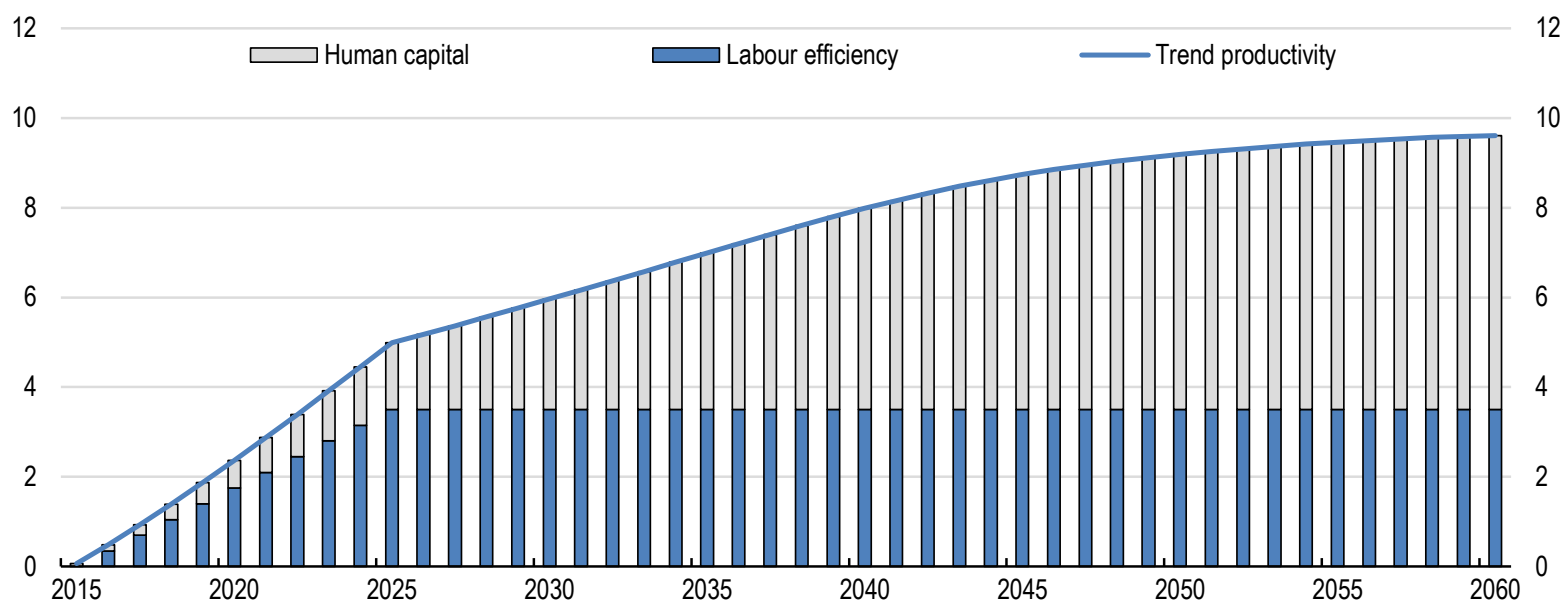

Source: OECD calculations.

18. In addition to the higher working age population induced by higher fertility, potential employment would benefit from a rising participation rate. First, this is due to the assumption of gradual increases in the female participation rate. Second, it is induced by a demographic effect as younger age cohorts exhibit relatively higher participation rates than older ones, and their share in the work force would gradually increase. By 2040, the simulation exhibits a $1 \mathrm{pp}$ increase of potential employment with respect to the baseline. This gap increases to 2pp in 2050 and to close to 4pp in 2060 (Figure 5) when demographic effects from an increase in fertility have materialised in all age-cohorts, in particular those with relatively high participation rates.

Figure 5. Implications for potential employment

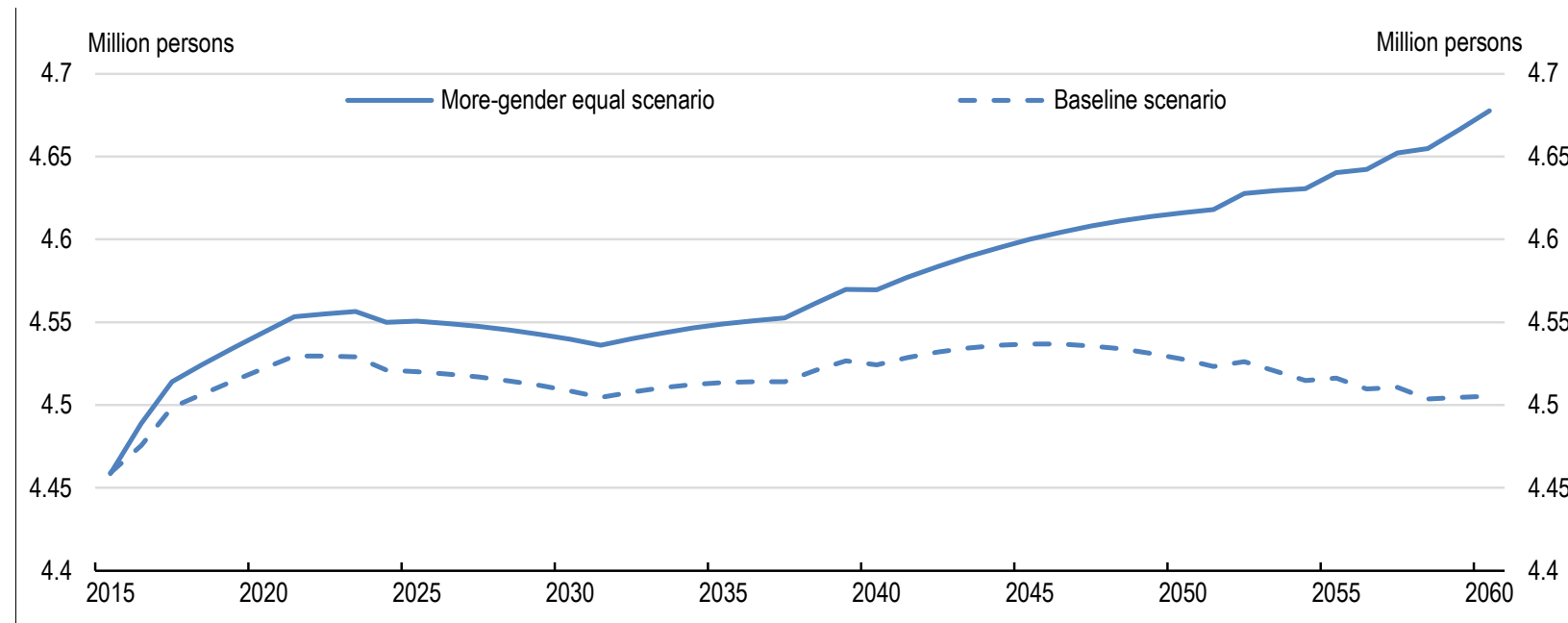

Source: OECD calculations 
19. Taken together, potential GDP is simulated to rise by about 13 percentage points in the more gender-equal scenario with respect to the baseline until 2060. Per capita GDP would increase by 8 percentage points and total population by approximately 4.5 percentage points, respectively (Figure 6 ).

Figure 6. GDP implications of more gender-equality

Percentage point increase from the baseline scenario to the more gender-equal scenario

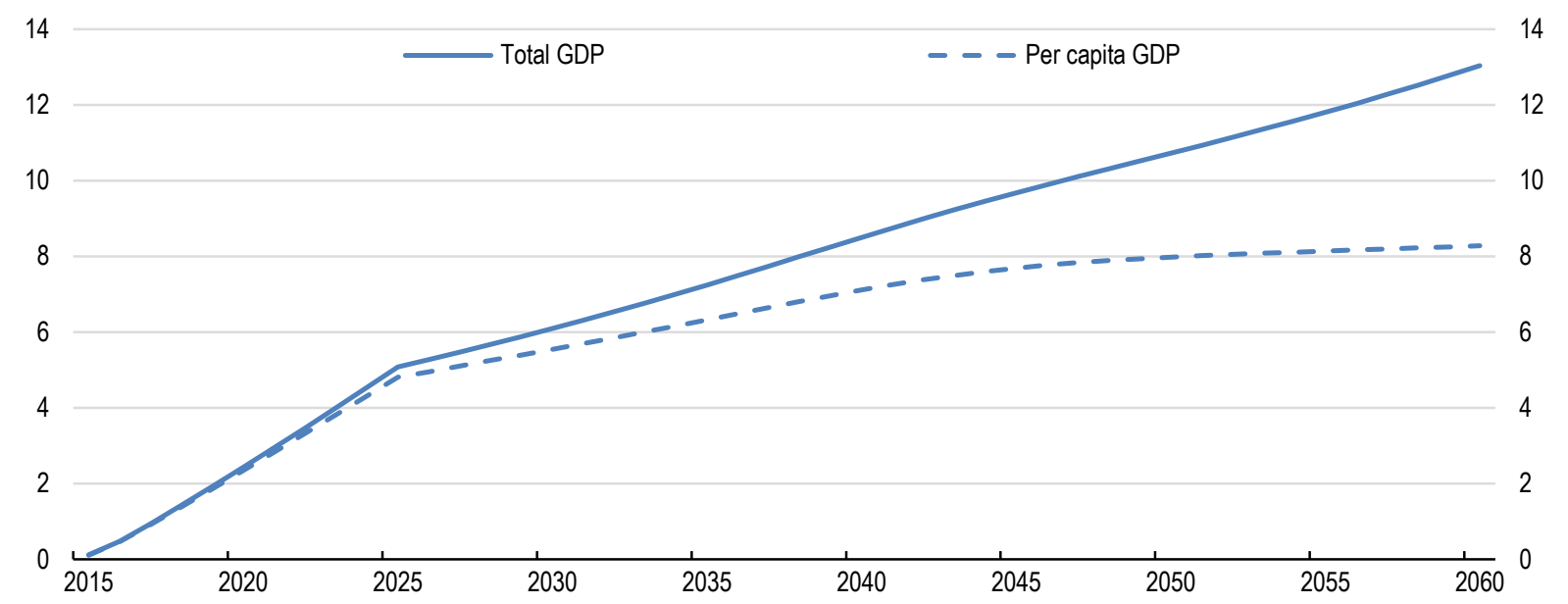

Source: OECD calculations based on OECD's long-term growth model (Box 2.2).

\section{An integrated policy framework to promote gender equality in Austria}

20. The Austrian government has launched a set of initiatives to raise awareness for gender inequalities and highlight the government's willingness to tackle them (Box 4). The gender mainstreaming agenda is underpinned by a Committee on Gender Equality, elected by parliament, that deals with all bills and legislative proposals related to gender equality, including women's and men's empowerment and the prevention of gender discrimination in all policy areas. Despite these efforts, some evidence calls for a stronger whole of government approach in Austria, including more robust processes for collecting genderspecific data, better and more systematic integration of gender analysis into the policy making process and a strengthening of monitoring, auditing and accountability measures (OECD, 2014b).

\section{Box 4. Current gender mainstreaming initiatives}

One of the prime examples for public action to foster gender equality in Austria is the gender budgeting project. It allows gender initiatives to make use of resources that go beyond the Federal Ministry of Education and Women's Affairs and can induce cultural change at the administrative and political level. Critics refer, however, to limited coordination across different bodies and levels of government. Objectives differ substantially in terms of quality and ambition, and the monitoring provided by the Federal Performance Management Office and the Parliamentary Budget Office has only limited power. It coordinates measures and targets across the different ministries by organising workshops, building up know-how and providing quality assessments and feedback. However, the budgetary impact of specific targets is not assessed. To remedy to this situation, the monitoring of spending associated with gender targets shall be provided by an independent gender budgeting council. Schratzenstaller (2014) further encourages a better link between medium-term gender objectives and gender-related long-term strategies at the EU level.

An initiative that extends awareness of gender inequalities beyond the public sphere is the requirement for income reports for companies with more than 150 employees. These compulsory reports result from the "National Action Plan for Gender Equality in the Labour Market" (2008-2013) and are a legal requirement under the Equal Treatment Act. The reports seek to improve income transparency and inform about gender-specific pay differences. 
They are also likely to trigger self-correction mechanisms as part of the dissemination process. Finally, the income reports reduce the extent of asymmetric information during the individual wage negotiation processes for both incumbent employers and outsiders. According to a survey jointly conducted by the Chamber of Labour (AK) and Austrian Trade Union Federation (ÖGB) and published in 2014, 71\% of the interviewed works councils found the income reports relevant and $63 \%$ affirmed that the content of the reports is useful. As a reaction to the income reports, $23 \%$ of the employers declared to deal with the apparent gender pay gap and $21 \%$ showed the willingness to concrete action such as training, measures to better reconcile work and family, female promotion plans or support for fathers in taking over family commitments.

In the absence of legislated regulation against sexist advertising, an advisory board on anti-sexism was created within the Austrian Advertising Council in 2011. The benefits of such a board are twofold. First, it allows for the monitoring of commercial audio-visual communication with respect to gender discriminatory advertising and enables the Advertising Council to stop campaigns if norms are violated. ${ }^{7}$ Second, it raises awareness in the advertising industry and may help to promote non-discriminatory portrayal of genders. To foster such progress, in 2012, the "Gender Award Advertising" initiative has been launched which rewards gender-sensitive advertising campaigns according to their extent of promoting gender equality by representing women and men in atypical roles and professions and thus overcoming gender stereotypes.

21. Raising awareness for the existence of gender inequalities and for the potential benefits of a more gender-equal society is a prerequisite for broad support for a gender mainstreaming policy agenda. Bringing in gender issues in the public debate through information campaigns or disseminating best practices can contribute to dismantling stereotypes such as the belief that a working mother is a bad mother (Rabenmutter) or that technical professions are male professions. It would help to motivate and underpin an integrated policy framework to achieve more gender-equality based on the following principles: $i$ ) make the tax-and-benefit system less gender role biased, ii) reconcile work and family lives by extending the service infrastructure and iii) encourage more flexible workplace practices.

\section{Make the tax and benefit system less gender role biased}

22. In many respects, the Austrian tax and benefit system is rather dual-earner friendly. Income taxation is individual which means that the entry tax rate for the second earner is smaller, all other things equal, than in joint or family-based taxation system. In addition, basic family allowances are rewarded universally, that is, independent from the level or distribution of earnings. On the other hand, certain characteristics of the tax and benefit system distort incentives in favour of the one bread-winner or the " $1 \frac{1}{2}$ model". In particular, the high marginal tax wedge for medium incomes is supportive of part-time work. The arrival of children reinforces this model through means-tested childcare allowances, sole-earner deductions, long parental leaves and a family benefit system largely tilted towards cash benefits.

\section{Eliminate work disincentives in the tax system}

23. Despite a significant reduction owing to the recent tax reform, Austria still has one of the highest bottom statutory rate in the OECD (declines from 36.5\% to 25\% in 2016, Box 1 and Figure 3, Panel A). In combination with a large zero-tax zone this leads to a substantial threshold effect at the point where the first tax bracket sets in. The transition from the zero-tax zone to the first income bracket merely concerns part-time employees and causes a considerable disincentive to extend working hours for employees whose income is close to but below the threshold of about EUR 17000 of annual gross earnings. ${ }^{8}$ Indeed, many female employees are concentrated in this part of the earning distribution (Gönenç et al., 2015).

7. In 2012, among the 278 complaints received by the Council more than a half dealt with gender discriminatory advertising and 13 campaigns have eventually been stopped.

8. Taking specific tax rates on holiday and Christmas bonuses and the deduction of social security contributions and standard tax allowances (Box 4) into account, the transition from the zero-tax zone to the 


\section{Box 5. Main features of Austria's personal income tax system}

Since 1973 individuals are taxed separately rather than jointly as a household. Annual gross earnings are usually divided into 14 equal monthly instalments of which 12 correspond to current monthly payments and the other 2 to holiday and Christmas bonuses. The tax schedules for these payments are different:

Tax schedule for personal income

\begin{tabular}{|c|c|c|c|c|c|}
\hline \multicolumn{2}{|c|}{ Until 31 Dec 2015} & \multicolumn{2}{|c|}{ From 1 January 2016} & \multirow[b]{2}{*}{$\begin{array}{c}\text { Holiday and } \\
\text { Christmas bonus in } \\
\text { Euros }\end{array}$} & \multirow[b]{2}{*}{$\begin{array}{c}\text { Marginal rate in } \\
\%\end{array}$} \\
\hline $\begin{array}{l}\text { Current taxable } \\
\text { income in Euros }\end{array}$ & $\begin{array}{l}\text { Marginal rate } \\
\text { in } \%\end{array}$ & $\begin{array}{l}\text { Current taxable } \\
\text { income in Euros }\end{array}$ & $\begin{array}{l}\text { Marginal } \\
\text { rate in \% }\end{array}$ & & \\
\hline $0-11000$ & 0.0 & $0-11000$ & 0.0 & $0-620$ & 0.0 \\
\hline $11001-25000$ & 36.5 & $11000-18000$ & 25.0 & $620-25000$ & 6.0 \\
\hline $25001-60000$ & 43.2 & $18000-31000$ & 35.0 & $25000-50000$ & 27.0 \\
\hline \multirow[t]{4}{*}{$60001+$} & 50.0 & $31000-60000$ & 42.0 & $50000-83333$ & 35.75 \\
\hline & & $60000-90000$ & 48.0 & $83334+$ & 50.0 \\
\hline & & $90000-1$ million & 50.0 & & \\
\hline & & 1 million + & 55.0 & & \\
\hline
\end{tabular}

Current taxable income is obtained as the sum of the 12 current monthly payments reduced by the employee's social security contributions and various tax allowances:

- Work related expenses for commuting, clothes, language courses, phone, etc. (lump sum of EUR 132)

- Special expenses: lump sum of EUR 60 or a quarter of expenses related personal insurance schemes, renovation or acquisition of principal residence. Maximum of EUR 2920 for singles and EUR 5840 for couples, with an additional EUR 1460 from three children onwards. Maximum allowance is limited to annual earnings up to EUR 36400 . Above EUR 36400 maximum allowance reduces gradually to reach EUR 60 at annual earnings of EUR 60000 and beyond. This part of special expenses relief will be abolished as of 1 January 2016. The lump sum of EUR 60 and costs related to contracts concluded before 2016 will be paid until 2020.

- Additional pay for overtime hours (up to $50 \%$ of the supplementary hourly wage) are exempt from income tax for the first 10 overtime hours (max. EUR 86 per month). Until 2009 only 5 overtime hours' allowances were tax-exempt.

The tax liability is obtained by applying the tax schedule to taxable income. Several tax credits then reduce the tax liability:

- Employee's tax credit: EUR 54. All employees are entitled.

- Commuter tax credit: EUR 291. Depending on availability of public transport and commuting distance, an additional commuter tax credit is paid. Thresholds are $2 \mathrm{~km}$ without public transport and $20 \mathrm{~km}$ with public transport available. The additional tax credit can reach up to EUR 3672 for commuting distances exceeding $60 \mathrm{~km}$ with no suitable public transport available.

Tax credits are non-wastable and paid out as negative tax up to $10 \%$ of paid social security contributions with a maximum of EUR 110 per year. Employees eligible for the additional commuting tax credit (see above) for long distances are entitled to an additional EUR 290 of non-wastable tax credits (EUR 400 in total) limited at $18 \%$ of paid social security contributions. As of 1 January 2016, tax credits will be granted up to EUR 400 for all employers and up to EUR 110 for pensioners limited at $50 \%$ of paid social contributions. For low-income commuters who do not pay income taxes, the negative tax credit can amount to maximal EUR 500.

first income bracket occurs at around EUR 17000 of gross annual earnings. Median gross annual earnings for full-time jobs amounted to slightly more than EUR 38000 in 2013 in Austria. 
24. The sole-earner deduction, which has not been addressed by the tax reform, provides disincentives for marginally employed second earner spouses. This tax allowance depends on the number of children and is rewarded to families whose second earner's annual taxable income does not exceed EUR 6000 (Box 6). For average hourly wages this threshold corresponds to approximately 9-10 hours per week. A marginal increase in the spouse's working time above 10 hours per week would effectively reduce the family's disposable income. This explains the local peak in the distribution of female earnings in the EUR 4 000-6 000 range (Gönenç et al., 2015).

25. A further disincentive for marginally employed workers is set by the threshold of currently EUR 405.98 below which no social security contributions are due. Above this limit, social security contributions are payable on the total amount of earnings resulting in an effective decrease in disposable income. Indeed, an employee earning EUR 477 per month actually ends up with the same net income of EUR 405 as an employee earning EUR 405 the difference being the social security tax liability (15.1\% or EUR 72 for the former, $0 \%$ for the latter). This threshold reinforces the effect of the sole earner tax credit and supports the male breadwinner model as well as the $1 \frac{1 / 2}{2}$ model.

26. Employee's and commuter tax credits (Box 5) are refundable and paid out as negative taxes to non-commuting (commuting) employees with an upper limit of $10 \%(18 \%)$ of paid social security contributions for a maximum of EUR 110 (EUR 400). At current contribution rates this means that incomes of non-commuting (commuting) employees below EUR 7300 (EUR 14 700) gradually loose entitlement to negative taxes. Below these thresholds, the negative tax has the effect of an in-work benefit. While the 2015/2016 tax reform is foreseen to lift the ceiling to EUR 400 (EUR 500) as of 1 January 2016, the fact that, the tax credits will be capped at $50 \%$ of paid social security contributions reduces the in-work benefit character as the ceiling will be hit earlier than before.

27. The tax exemption for the supplement awarded for overtime hours (Box 5) is another tax measure that encourages an unequal distribution of paid work between the two partners as it provides an incentive to increase working time beyond the regular working hours. Indeed, in Austria, the male bread winners bear the bulk of overtime hours and Austrian men are the OECD champions of weekly hours worked. This obviously makes them less available at home and reinforces the separate gender role model (Gönenç et al., 2015).

\section{Family benefits need to be better targeted to offer real choice}

28. In sharp contrast to the OECD average, spending on family benefits as a share of GDP has declined in Austria since the beginning of the 2000's. As of 2011, overall spending on family benefits in Austria amounted to $2.7 \%$ of GDP which was only slightly above OECD average of $2.6 \%$ of GDP and substantially below spending by countries of the top third (3.7\%) (Figure 7). The breakdown into spending categories varies substantially across countries. While the average OECD country allocates about half of its spending to cash benefits, cash transfers account for three quarters of the family related spending in Austria. Tax breaks are barely used at all and benefits in-kind fall significantly short of what can be observed in peer countries and the OECD as a whole.

29. On the one hand, cash benefits prove to be an effective tool to reduce child poverty and inequality (Förster and Verbist, 2012). On the other hand, they are less effective in pursuing other policy objectives such as maximising labour force participation, in particular, if, as is the case in Austria, none of the cash transfers are conditional on the use of childcare services. Against this background, a shift from cash towards in-kind benefits and tax-breaks could rebalance the provision of family benefits in favour of parents in employment and support the compatibility of career and family life, in particular for mothers of young children. 
Figure 7. Public spending on family benefits

In per cent of GDP, 2011

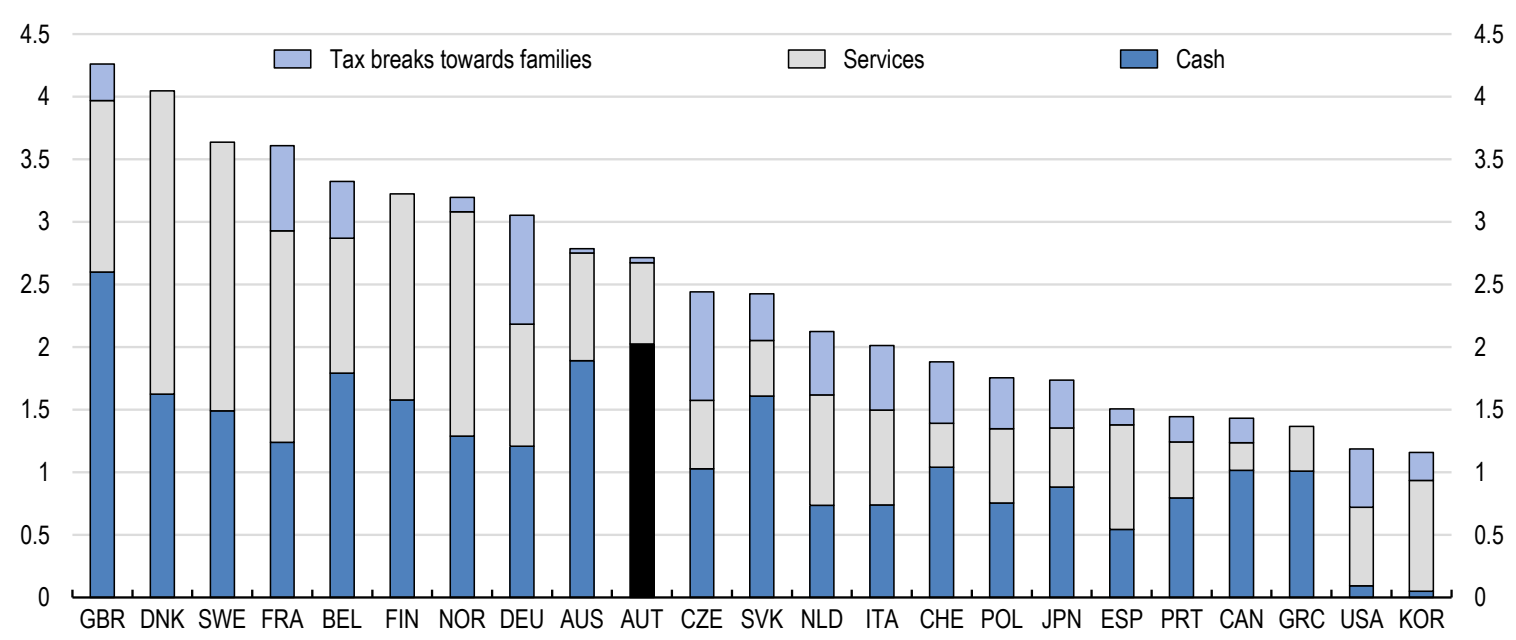

Source: OECD (2014), Family database (www.oecd.org/social/family/database.htm)

30. The voucher system that supports families that make use of formal ECEC services should be extended to all parents and streamlined with the general scheme of public childcare allowances (Box 6). Currently, the maximum amount of the voucher that employers can grant to their employees is EUR 500 per year, while the unconditional childcare allowance ranges from EUR 436 to EUR 2000 per month. Especially for low-income families, the costs of formal childcare may exceed earnings prospects for the second earner, in particular, if regularly provided formal childcare facilities are not available or do not cover the full day. More in-kind benefits would give a stronger focus on earlier years of the child's development for which Austria spends a considerably lower share than other OECD countries (Figure 8). This lowers return on investment in human capital that is found to be highest for the earliest years (Heckman, 2006).

Figure 8. Public spending on family benefits and education by age

In per cent of GDP

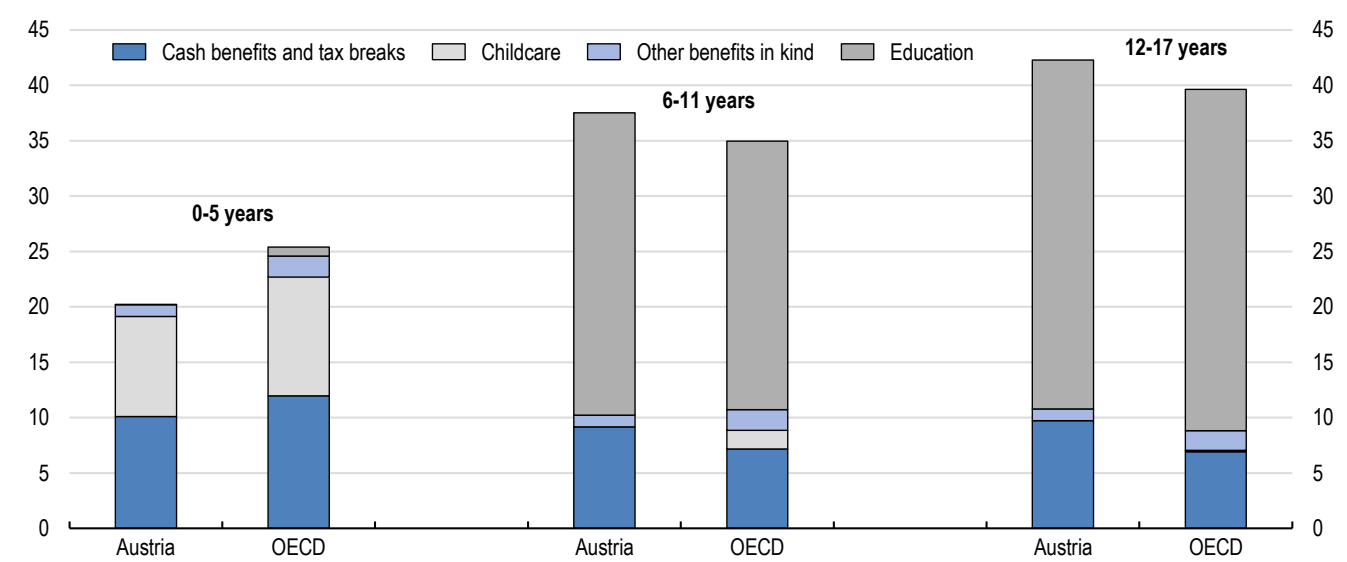

Note: The indicator is calculated using the Age-Spending Profiles methodology used in Doing Better for Families (OECD, 2011). Preliminary 2011 data for Austria. Data for the OECD refer to 2009.

Source: Source: OECD, Social Expenditure Database and OECD Education database, 2014. 


\section{Box 6. The current system of family benefits}

The bulk of spending on family benefits is paid out in cash (74.6\%) most of which non-means-tested. Tax breaks only represent $1.5 \%$ and in-kind benefits $23.9 \%$ of total spending on family benefits.

\section{Cash benefits}

Family allowances are granted universally for each dependent child independent from the number of earners or the level of earnings in the family. Dependent children are all children aged 18 years or younger, or between 19 and 24 as long as their income does not exceeding EUR 10000 per year. Allowances are decomposed in a basic allowance of EUR 109.70 per child and month, an age supplement and a sibling supplement (Table below). Family allowances will be augmented by $1.9 \%$ in 2016 and again by $1.9 \%$ in 2018 .

Monthly family allowance per depend child and month

\begin{tabular}{rccccccc}
\hline & \multicolumn{7}{c}{ total number of dependent children } \\
Child's age & 1 & 2 & 3 & 4 & 5 & 6 & 7 \\
\hline 0-2 years & 109.7 & 116.4 & 126.3 & 135.2 & 140.5 & 144 & 159.7 \\
3-9 years & 117.3 & 124.0 & 133.9 & 142.8 & 148.1 & 151.6 & 167.3 \\
$10-18$ years & 136.2 & 142.9 & 152.8 & 161.7 & 167.0 & 170.5 & 186.2 \\
$19-24$ years & 158.9 & 165.6 & 175.5 & 184.4 & 189.7 & 193.2 & 208.9 \\
\hline
\end{tabular}

Source: Federal Ministry for Family and Youth. As of October 2014. Currency: Euro.

Additionally, a "school supplement" of EUR 100 is rewarded every September for children aged between 6 and 15. Families are further entitled to a non-wastable tax credit of EUR 58.40 per month and child. This tax credit is paid out independently from the income tax regime and meets the condition of a cash benefit. The only means-tested cash benefit is a "multiple child" supplement of EUR 20 per month, granted for the $3^{\text {rd }}$ and any additional child provided that the family's taxable income does not exceed EUR 55 000. A supplement for families in need is available at the Länderlevel. Eligibility criteria and amount of these means-tested cash transfers vary substantially from one Land to another.

\section{Tax allowances}

- Sole earner deduction: single parents and couples where the second earner's income does not exceed EUR 6000 per year are entitled to a deduction from their taxable income: EUR 494 per year for the first child, 175 for the second child and EUR 220 for the $3^{\text {rd }}$ and any additional child.

- A single parent tax payer can deduct EUR 220 per child from the annual taxable income while two parents have the choice between deducing EUR 220 for one parent or EUR 132 each. To be eligible, the tax payer must be entitled to the children tax credit (EUR 58.40 per month, see above) for the corresponding child for more than 6 months during the reference year. In the course of the 2015/2016 tax reform, it is planned to double the tax allowance per child to EUR 440.

\section{In-kind benefits}

In-kind benefits include direct financing of childcare or subsidising providers of childcare facilities. It amounts to $0.65 \%$ of GDP, that is, approximately a fourth of total spending on family benefits. Since 2009 , employers can grant a childcare subsidy to the employee of up to EUR 500 per year for children under ten years of age conditional on the use of an formal childcare facility or a licensed child minder. The subsidy can be paid either directly to the facility or to the care giver either in cash or as a voucher to be cashed in at a facility of her choice. The subsidy is exempt from taxation and social security contributions.

31. In its 2013-18 work programme, the Austrian government has acknowledged the need to provide "more transparency and simplification regarding family benefits". The 2013 OECD Economic Survey's review of the system of family benefits has highlighted the complexity of the system. The wide range of instruments across different levels of governments, with regional differences, can lead to inequalities due to lack of information or simply due to the place of living. In 2012, Länder-specific transfers to families in need amounted to $7 \%$ of total spending on family benefits at the federal level (among recipient families the 
share of Länder transfers is much higher). Eligibility criteria and amount varied considerably across the Länder which, inter alia, leads to regional inequalities, in particular, among poor families. A general effort to streamline benefits across different levels of government, horizontally and vertically, would reduce inequalities and inefficiencies, in particular, as financing responsibilities and provision of the benefits often do not lie in the same hands.

32. De Boer et al. (2014) evaluate the impact of fiscal stimuli likely to support working parents (Box 7). They use a structural model calibrated on recent reforms in the Netherlands and administrative data for hours worked and the use of formal childcare. The results suggest that a combination of meanstested in-work benefits for secondary earners and targeted subsidies for childcare services have the strongest potential to support working parents in a cost-efficient way. The findings are likely to bear interest among Austrian policymakers and may give rise to discussion about innovations in the tax and benefit system.

\section{Box 7. Estimating the efficiency of support policies for working parents}

The Netherlands Bureau of Economic Policy Analysis produced a pioneering analysis of the efficiency of alternative support schemes for working parents (de Boer et al., 2014). The researchers suggest that their "findings are relevant for the effectiveness of these policies in other developed OECD countries".

The Netherlands' highly varied experience with support schemes for working parents (following several reforms over the past decade), and the availability of high quality information on households' labour market position, tax liabilities, social benefits and child care practices over the same period permitted to estimate a large structural model, which helps simulate the responses of different types of households to alternative policy schemes. Only couple families with children less than 12 year old are covered. The model simulates their decisions in the face of different incentives, and helps calculate "net employment gains per euro of public spending" under different schemes. It takes into account second round fiscal effects from changes in workers' behaviour and seems to have a good fit with actual experience so far.

The model has been used to estimate likely gains from a fictitious EUR 100 million support package for working parents. The impacts of three main types of policy schemes currently in use in OECD countries (and which have been utilised in the Netherlands in the past) were investigated: i) a rise in childcare subsidies (cutting the childcare fees for dual-working parents); ii) in-work tax credits granted to all working parents; and iii) in-work benefits granted to all second earners. Two variants of each scheme have been tested: $i$ ) universal benefits at a flat rate, granted to all families; and ii) income-dependent benefits reserved to mid- to high-income households. Simulation results differ significantly between policy options, in all respects, and the net fiscal cost of an additional full-time job ranges from EUR 29000 to EUR 180 000. The most significant findings are:

- $\quad$ A strong increase in universal childcare benefits enhances total work hours, but is costly. It has little impact on men's total labour supply (slight increase in their labour force participation, to qualify for benefits, but also a reduction in work hours). Impacts on women's labour force participation and work hours are both significant and positive. Yet, the impact on child care use is even stronger, suggesting that part of the increase in subsidised child care does not directly support labour force participation. In this scheme, a high share of child care costs end up being publicly funded (76\% in average, up to $96 \%$ for low-income households), explaining the high budget cost of EUR 50000 per full-time job created.

- $\quad$ An increase in childcare benefits for middle-to-high income families increases total work hours in the same proportion, but at a lower fiscal cost. Women's labour supply increases less than above (there is an income effect for higher earning women, which slows their participation), but high earning men's labour supply is resilient. As childcare costs are in the first place less subsided for these households (by about $40 \%$ ), their broader recourse to additional care after this incentive is less fiscally costly. Moreover, these families' higher work hours generate higher tax revenues. This second variant of childcare support is more efficient (EUR 40000 per full-time job created) but comes at an equity cost. Income inequality increases, and children from low income families participate less in formal child care.

- The allocation of the EUR 100 million into flat in-work benefits for all working parents has a very weak simulated impact. The bulk of transfers go to men, who have a largely inelastic labour supply. Effects on second earners are more positive, but are diluted (subsidies are spread thin). When in-work benefits are targeted to mid-to high income families, the effects are more tangible, but in both cases the schemes are 


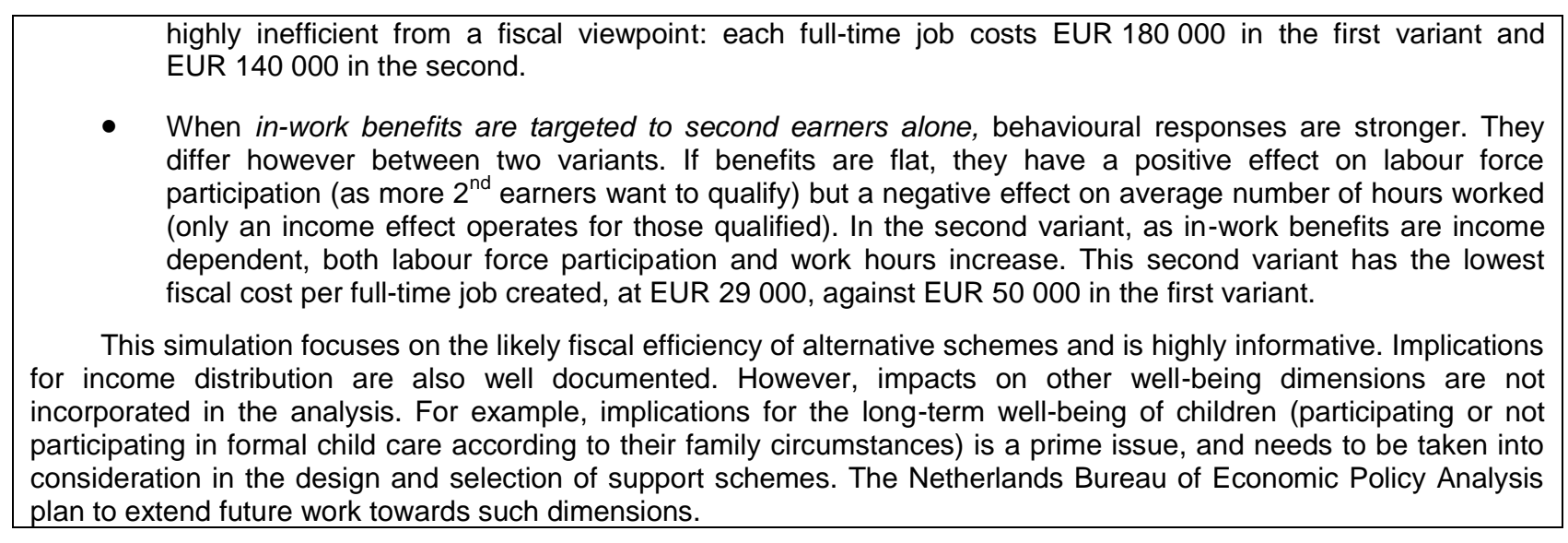

\section{Promote a more gender-equal parental leave system}

33. Parental leave policies are in general complex and vary considerably across countries. The main discriminant parameters of parental leave systems are $i$ ) the duration and ii) wage replacement rates and iii) eligibility and transferability criteria for mothers and fathers. Generous parental leaves can facilitate child bearing decisions but also affect other outcomes, in particular the child's development and the parents' employment pattern. Maternal and paternal presence until a child has reached at least 6 months is generally judged as positive for the child's psychological and cognitive development, not the least related to breastfeeding. Beyond the 6 months, effects of in-house versus formal childcare on the child's cognitive and non-cognitive depend, inter alia, on the educational background of parents and their parenting skills (Huerta et al., 2011). In terms of employment outcomes, leave schemes can strengthen the mother's tie to paid work and uphold women's employment rate. This is usually associated with rather short leave durations of below 1 year. On the other hand, absence from work can have adverse consequences for the parent's, mostly the mother's, human capital and future employment opportunities. Such hysteresis patterns typically increase with the duration of the leave taken. Since parental leaves, especially longer spells of absence, are generally taken up by women, longer durations are likely to sharpen genderinequalities in the labour market.

Table 3. Distinct childcare allowance variants in Austria

\begin{tabular}{|c|c|c|c|c|c|}
\hline & Model $30+6$ & Model $20+4$ & Model 15+3 & Model $12+2 \mathrm{~A}$ & Model $12+2 \mathrm{~B}$ \\
\hline Payment & EUR 436 & EUR 624 & EUR 800 & EUR 1000 & $\begin{array}{l}80 \% \text { of average of } \\
\text { last months' salary; } \\
\text { max. EUR } 2000\end{array}$ \\
\hline $\begin{array}{l}\text { Entitlement for } 1 \\
\text { parent }\end{array}$ & 30 months & 20 months & 15 months & 12 months & 12 months \\
\hline $\begin{array}{l}\text { Additional entitlement } \\
\text { for } 2^{\text {nd }} \text { parent }\end{array}$ & 6 months & 4 months & 3 months & 2 months & 2 months \\
\hline $\begin{array}{l}\text { Max. authorised } \\
\text { additional income }\end{array}$ & $\begin{array}{l}60 \% \text { of annual } \\
\text { salary of } \\
\text { reference year; } \\
\text { min EUR } 16200\end{array}$ & $\begin{array}{l}60 \% \text { of annual } \\
\text { salary of } \\
\text { reference year; } \\
\text { min EUR } 16200\end{array}$ & $\begin{array}{l}60 \% \text { of annual } \\
\text { salary of } \\
\text { reference year; } \\
\text { min EUR } 16200\end{array}$ & $\begin{array}{l}60 \% \text { of annual } \\
\text { salary of } \\
\text { reference year; } \\
\text { min EUR } 16200\end{array}$ & EUR 6400 \\
\hline $\begin{array}{l}\text { Additional state aid } \\
\text { for low income } \\
\text { families }\end{array}$ & $\begin{array}{l}\text { EUR } 180 \text { during } \\
\text { max. } 12 \text { months }\end{array}$ & $\begin{array}{l}\text { EUR } 180 \text { during } \\
\text { max. } 12 \text { months }\end{array}$ & $\begin{array}{l}\text { EUR } 180 \text { during } \\
\text { max. } 12 \text { months }\end{array}$ & $\begin{array}{l}\text { EUR } 180 \text { during } \\
\text { max. } 12 \text { months }\end{array}$ & - \\
\hline
\end{tabular}

Note: The state aid supplement is conditional on earnings being below EUR 6400 for the recipient and below EUR 16200 for the spouse.

Source: Austrian Federal Ministry of Families and Youth. 
34. After the obligatory maternity leave ( 8 weeks before and 8 weeks after the birth), the Austrian system grants a parental leave to parents that lasts at most until the $2^{\text {nd }}$ birthday of the child. The leave is a family entitlement and can be shifted from one parent to the other twice for a total of three distinct spells, each of which has to last at least 2 months. It cannot be taken simultaneously. There is no specific paternity leave entitlement except for public sector workers who can take 1 month of unpaid leave. ${ }^{9}$ The childcare allowances (Table 3) are in principal independent from the parental leave entitlement. However, periods of childcare allowance entitlements do in general coincide with parental leaves due to the eligibility criteria of the former. Other than the actual parental leave, each childcare allowance variant has a, albeit short, nontransferable component for the $2^{\text {nd }}$ parent, usually the father. ${ }^{10}$ Although less so than in the past, the vast majority of Austrian parents still opt for childcare allowance variants lasting at least 2 years, hence longer than the job-protected leave entitlement (Table 4).

Table 4. Take up distribution of childcare allowance variants

\begin{tabular}{lccccc}
\hline \multicolumn{5}{c}{ Year of the child's birth } \\
\hline & $\begin{array}{c}2010 \\
\%\end{array}$ & $\begin{array}{c}2011 \\
\%\end{array}$ & $\begin{array}{c}2012 \\
\%\end{array}$ & $\begin{array}{c}2013 \\
\%\end{array}$ & $\begin{array}{c}2014 \\
\%\end{array}$ \\
\hline Model 30+6 & 53 & 49 & 44 & 40 & 37 \\
Model 20+4 & 25 & 26 & 26 & 27 & 27 \\
Model 15+3 & 6 & 6 & 6 & 6 & 6 \\
Model 12+2 A & 5 & 5 & 6 & 6 & 7 \\
Model 12+2 B & 12 & 14 & 18 & 21 & 23 \\
\hline
\end{tabular}

Source: Federal Ministry for Family and Youth. As of March 2015.

35. Official statistics on the take up of parental leaves by mothers and fathers are not available but the distribution of childcare allowances by gender is likely to reflect the distribution of leave taken (Table 5). The numbers illustrate that only a small share of Austrian fathers take parental leave. In addition, those who do typically take not much more than the duration defined by the non-transferable amount of months of the chosen variant. Fathers also tend to participate more in shorter better remunerated variants. In total, only $18 \%$ of fathers participate in parental leave arrangements. Fathers usually take not much more than the months reserved for them, between 2 and 8 months, according to the chosen variant (Table 5). This is consistent with international evidence that fathers make little use of parental leave when it is provided as a family entitlement (Moss, 2012) and that they make more use of it in countries with individual and well-paid entitlements, such as in the Nordic countries.

Table 5. Fathers' involvement in parental leave

\begin{tabular}{lcccccc}
\hline & \multicolumn{3}{c}{ Year of the child's birth } & \multicolumn{2}{c}{ Father's } \\
& $\begin{array}{c}2009 \\
\%\end{array}$ & $\begin{array}{c}2010 \\
\%\end{array}$ & $\begin{array}{c}2011 \\
\%\end{array}$ & $\begin{array}{c}2012 \\
\%\end{array}$ & $\begin{array}{c}2013 \\
\%\end{array}$ & $\begin{array}{c}\text { share in } \\
\text { months } \\
\text { (averages) }\end{array}$ \\
\hline Model 30+6 & 12 & 11 & 11 & - & - & 7.8 \\
Model 20+4 & 18 & 19 & 18 & 18 & - & 5.2 \\
Model 15+3 & 26 & 28 & 28 & 27 & - & 4.2 \\
Model 12+2 A & 35 & 30 & 30 & 29 & 28 & 3.5 \\
Model 12+2 B & 26 & 26 & 26 & 27 & 29 & 2.7 \\
\hline
\end{tabular}

Source: Federal Ministry for Families and Youth. As of March 2015.

9. Some collective agreements contain provisions for 1 month of paid or unpaid paternity leave.

10. In case of hardship, sole parents can benefit from 2 additional months but do not have access to the months reserved for the second parents. 
36. In sum, mothers tend to choose longer durations of leave while fathers tend to do the opposite. Back on the job, the resulting adverse consequences for women with respect to men are sustainable and widely documented (Riesenfelder, 2013). The share of women (men) that earn more than EUR 2000 drops from $45 \%(52 \%)$ the year prior to parental leave to $3 \%$ (34\%) during the first year of parental leave and only recovers to the level of $17 \%$ (50\%) during the fourth year following the start of the parental leave. A great part of this long-lasting negative impact on mothers' earnings is related to the transition to part-time subsequent to the parental leave. If they have a tenure of 3 years prior to the birth of the child, parents working in companies with at least 20 employees are entitled to part-time work until the child turns 7 years old. As discussed above, the tax and benefit system encourages the use of part-time or marginal employment for one parent while the other is working full-time. To the extent that mothers take longer leave, the interplay of leave policies, childcare allowance eligibility criteria and fiscal incentives explains the significant wedge between part-time prevalence of mothers and fathers of young children documented in Gönenç et al. (2015).

37. Transforming the parental leave entitlement into a more flexible time account that would allow parents to return earlier to work and save some of their entitlement for later stages of the child's education (pre-school or early school years, for example) would be welcome. Childcare allowance and parental leave schemes could be transformed into a unique childcare allowance account that allows parents to allocate subsidised absence from work flexibly over time. A sizeable part of this account, at least $33 \%$, should be reserved to the exclusive use of fathers to strengthen labour market attachment of both fathers and mothers without jeopardising care and family commitments.

38. For instance, the account could be calibrated to a total absence of 18 full-time months, at least 6 of which are reserved to the father, with a total entitlement of up to EUR 30000 (which would make it slightly more generous than the current income-dependent variant). Monthly allowances could be limited to $80 \%$ of the earnings of the highest earner's income prior to the birth of the child (max EUR 1 667) for full absence from work (adjusted in pro-rata terms for part-time work/absence). Work intensity, allocation across partners and across time can then be chosen by the parents subject to agreements with their employers. Some possibilities of its use, all equivalent in terms of total absence and transfers received ${ }^{11}$, are illustrated in Table 6. Importantly, absences from work can coincide between the 2 parents without a loss in entitlement. Further, absences could be split in several spells until, for instance, the child's $8^{\text {th }}$ or $15^{\text {th }}$ birthday. These options are outlined to illustrate the flexibility and potential of the single account concept, which lends itself to additional possibilities and features according to evolving consensuses in society and practical experience.

11. Assuming that the highest earners' income prior to the birth of the child was at least EUR 1875 (80\% of which correspond to the ceiling of EUR 1500 ). 
ECO/WKP(2015)91

Table 6. Possible use of a unique childcare allowance account

\begin{tabular}{|c|c|c|c|c|c|c|}
\hline \multirow[b]{2}{*}{ Variant } & \multicolumn{3}{|c|}{ Father } & \multicolumn{3}{|c|}{ Mother } \\
\hline & $\begin{array}{c}\text { Reduction } \\
\text { of working } \\
\text { time } \\
\%\end{array}$ & $\begin{array}{l}\text { Duration } \\
\text { (Months) }\end{array}$ & $\begin{array}{l}\text { Monthly } \\
\text { allowance } \\
\text { (Euros) }\end{array}$ & $\begin{array}{c}\text { Reduction } \\
\text { of working } \\
\text { time } \\
\%\end{array}$ & $\begin{array}{l}\text { Duration } \\
\text { (Months) }\end{array}$ & $\begin{array}{l}\text { Monthly } \\
\text { allowance } \\
\text { (Euros) }\end{array}$ \\
\hline Standard parental leave & 100 & 6 & 1667 & 100 & 12 & 1667 \\
\hline Standard part-time leave & 50 & 12 & 833 & 50 & 24 & 833 \\
\hline Equal-shared parental leave & 100 & 9 & 1667 & 100 & 9 & 1667 \\
\hline Equal-shared part-time leave & 50 & 18 & 833 & 50 & 18 & 833 \\
\hline Mother works 4 days after & & & & 100 & 6 & 1667 \\
\hline $\begin{array}{l}\text { initial shared } 6 \text { months } \\
\text { parental leave }\end{array}$ & 100 & 6 & 1667 & $\begin{array}{l}+ \\
20\end{array}$ & $\begin{array}{c}+ \\
30\end{array}$ & + \\
\hline $\begin{array}{l}\text { Father works part-time } \\
\text { during the mother's } 1 \text { year } \\
\text { leave }\end{array}$ & 50 & 12 & 833 & 100 & 12 & 1667 \\
\hline Both work 4 days & 20 & 45 & 333 & 20 & 45 & 333 \\
\hline Both work 3 days & 40 & 22.5 & 667 & 40 & 22.5 & 667 \\
\hline
\end{tabular}

Note: Based on the proposed design of a unique childcare allowance account calibrated to 18 months of fulltime absence from work and an allowance amounting to $80 \%$ of the highest earner's income prior to the birth of the child (max EUR 1667 ). The illustrated amounts assume that the highest earner's income exceeded EUR 1875 which entitles the parents for a monthly allowance of EUR 1667 in case of a complete absence from work (EUR 833 for part-time absence, etc.). Cumulated allowances received in all variants sum up to EUR 30000.

\section{Reconcile work and family lives by extending the service infrastructure}

\section{Promote more efficient supply of childcare services}

39. The availability of formal childcare is a precondition for combining full-time work with care chores induced by the presence of young children, in particular following parental leaves. Opening-up work-life patterns by waiving the aforementioned work disincentives is indeed not sufficient to reduce the burden of having to choose between work and family if external care is not available. Childcare infrastructure, in particular for children under 3-years of age, is largely underdeveloped in Austria (Figure 9). As of 2010, enrolment rates for under 3-years are among the lowest in the OECD and coverage of 3-5 years olds also stays far behind most peer countries. 
Figure 9. Participation rates in childcare among children aged 0-5

In per cent of the age group population

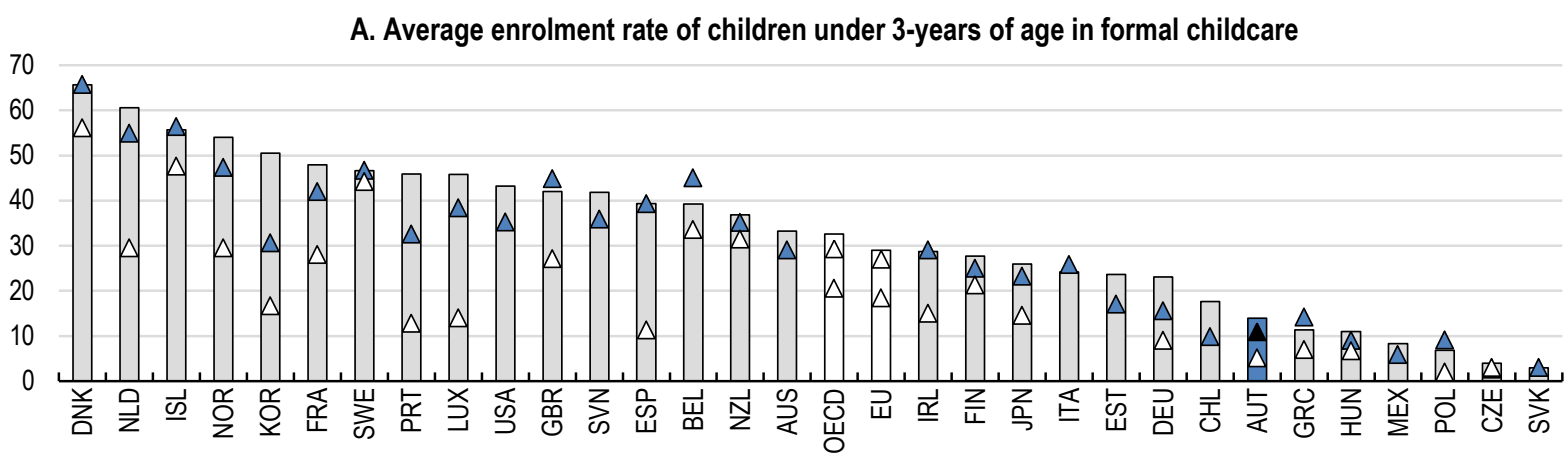

B. Average enrolment rate of children aged 3-5 years of age in pre-school educational programmes

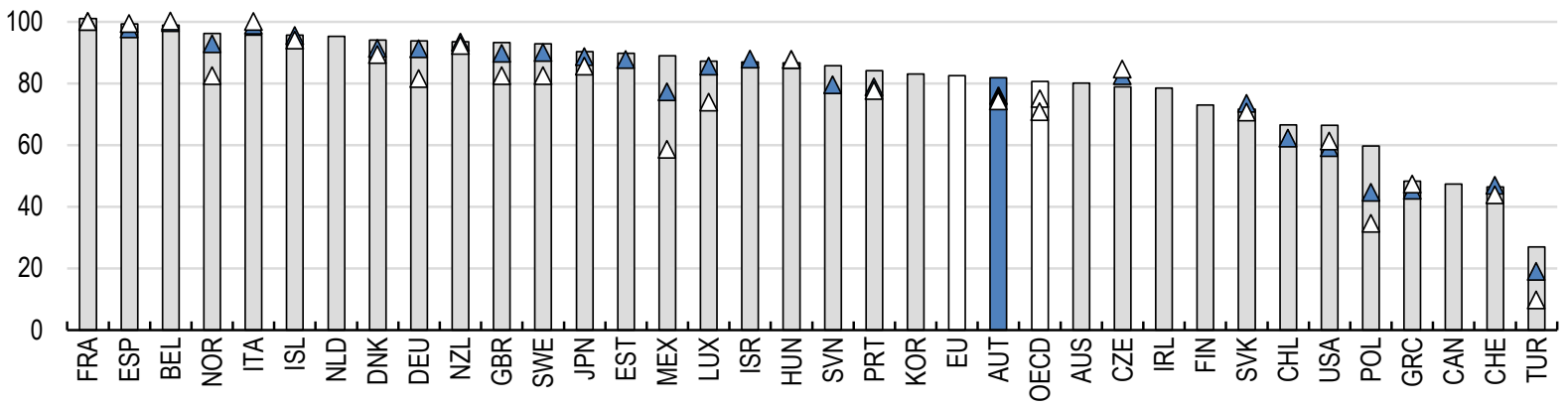

Source: OECD (2014), Family database (www.oecd.org/social/family/database.htm).

40. From 2010 to 2013, enrolment rates have increased, with very significant progress made in Vienna (Figure 10), but the rates are still far below those reached in other OECD countries in general and in peer countries in particular. As shown in Gönenç et al. (2015), the numbers also reveal important regional differences both in terms of level of participation and in terms of catch-up velocity. Overall, the extent of enrolment in early childhood care and education facilities is consistent with the observed long durations of parental leaves, generally taken up by the mother. 
Figure 10. Participation of under 3-year-olds in formal childcare services

Enrolment rates, in per cent of population under 3-year-olds

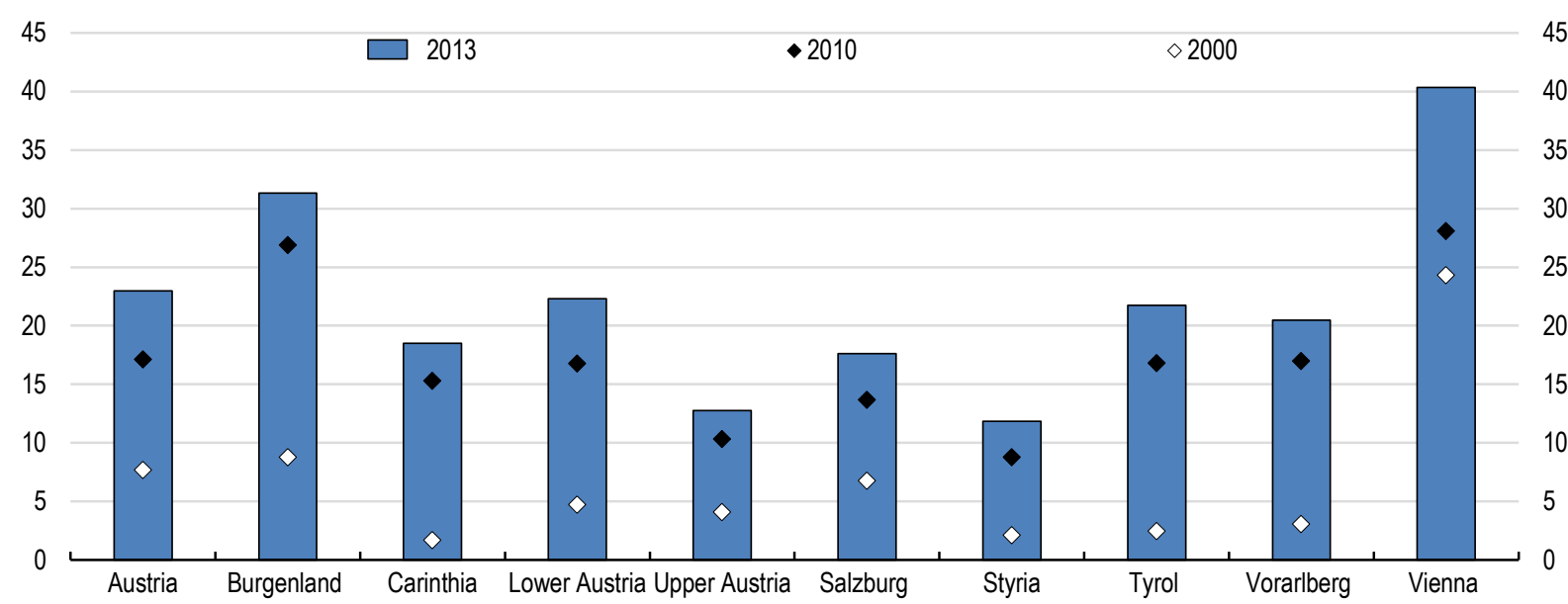

Source: Statistik Austria.

41. Enrolment rates for 3-5 year olds in formal childcare are closer to the OECD average but still far lower than what is observed in comparable countries (Figure 9). In addition, with the exception of Vienna, the vast majority of facilities are not compatible with a dual-earner full-time family as opening hours and days are very restricted (Figure 11). Especially in rural areas, where commuting distances are longer, this represents a genuine obstacle for working parents. In 2008, a specific agreement between the federal state and the Länder has defined government support criteria for day-care centres according to the level of compatibility with both parents' fulltime work. Day-care centres are categorised in 3 groups according to the degree of compatibility with fulltime working parents:

- Half-day: min. 30 weeks per year; min. 4 hours per day on average; min. 20 hours per week.

- Full-day: min. 30 weeks per year; min. 6 hours per day on average; min. 30 hours per week; includes lunch.

- Full-time-work-compatible (VIF label): min. 47 weeks per year, min. 45 hours per week, each week min. 91/2 hours on at least 4 days; includes lunch.

42. The alignment of subsidies with the degree of compatibility with fulltime work is a welcome initiative. As of 2011, only the city of Vienna offered sufficient supply of formal childcare facilities that were compatible with dual-earner families where both parents work fulltime (Figure 11, Panel A). So far, annual reports on childcare facilities (Kindertagesheimstatisik) do not provide the breakdown in VIF and non-VIF day-care centres but the report $2014 / 15$ is expected to contain a corresponding table. The dissemination of such a statistic is important as it raises the awareness for the need to reconcile work and family and can foster inter-regional emulation. 
Figure 11. Enrolment of children by type of care facility, age, region and degree of urbanisation

In per cent of the age group population, 2011
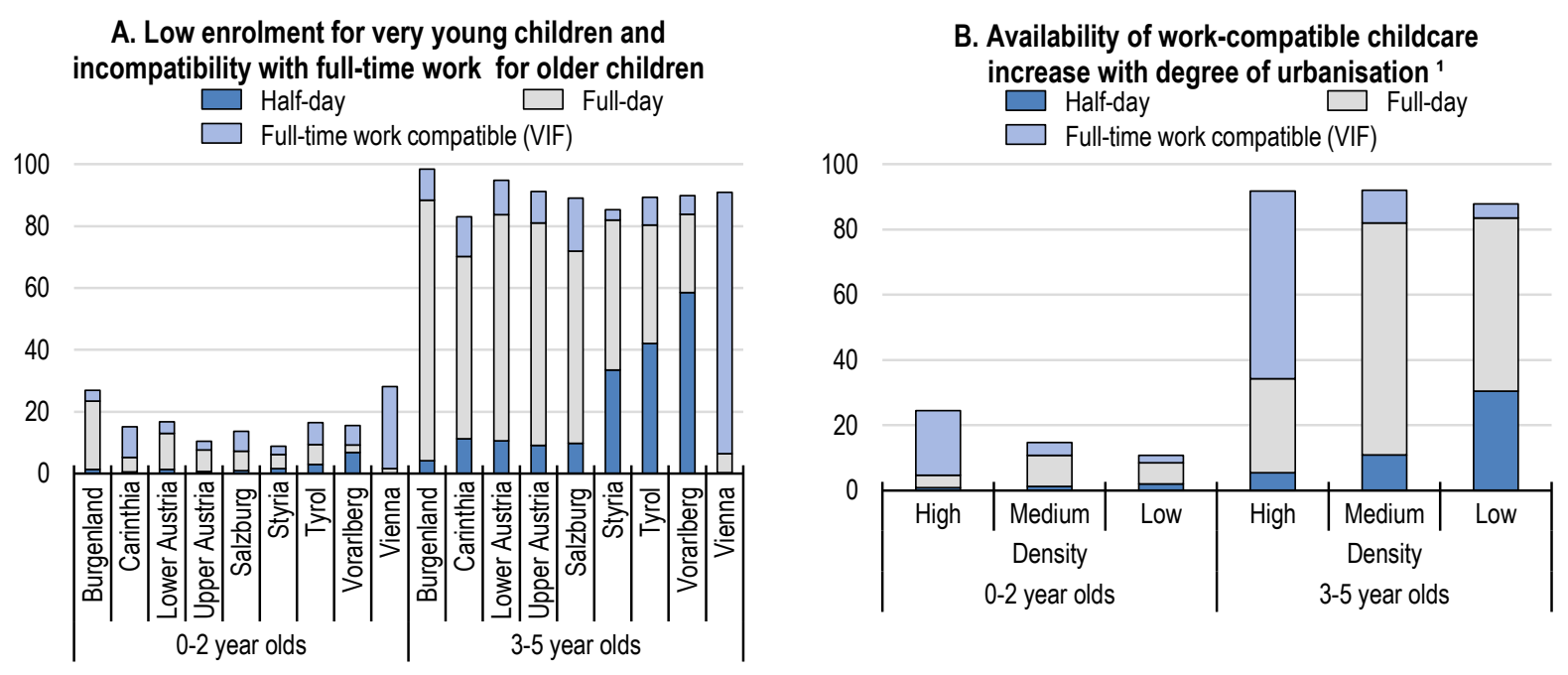

Note: Day-care centres are categorised in 3 groups according to the degree of compatibility with fulltime working parents:

- Half-day: min. 30 weeks per year; min. 4 hours per day on average; min. 20 hours per week;

Full-day: min. 30 weeks per year; min. 6 hours per day on average; min. 30 hours per week; includes lunch;

Full-time-work-compatible (VIF label): min. 47 weeks per year, min. 45 hours per week, each week min. $91 / 2$ hours on at least 4 days; includes lunch.

1. High, medium and low refer to the population density in the respective municipality according to the Eurostat definition.

Source: Statistik Austria.

43. Weak demand for formal childcare, while partly driven by traditional beliefs that children should be taken care of at home, is sometimes also explained by the low level of social recognition of public childcare institutions (Austrian Institute for Youth Research, 2004). First, the socio-economic consideration of childcare workers is undermined by the fact that Austria is the only OECD country where pre-school teachers are not required to undergo tertiary education (OECD, 2011d). Qualification requirements could be aligned with those in peer countries in order to increase quality and acceptance of formal childcare services and education and to make the profession more attractive. Second, despite the low enrolment, the child-to-staff ratio in Austria is among the highest in the OECD, which may discourage some parents to send their child to day-care centres. Austria only spends $0.65 \%$ of GDP on services for families with children, notably early childhood education care facilities. This is far below the spending in the upper third of OECD countries (1.04\%). Nordic countries spend more than $2 \%$ of GDP on financing or subsidising childcare facilities. Investing in early childhood care and education is arguably one of the public investments with the highest rates of return for the society. It sets the base for cognitive and noncognitive developments of the children, allows parents to reconcile family and work and may even encourage child-bearing decisions.

44. In total, substantial improvement in the coverage of early childhood care and education both at the extensive margin (number of places) and at the intensive margin (opening hours of care facilities) is necessary in order to provide an enabling infrastructure for parents that allows for the combination of work and family duties. A cost-benefit analysis provided by the Austrian Federal Chamber of Labour (2013) analyses the expenditures and revenues of a gradual increase in the number of 35000 childcare places, extended opening hours for 70000 places and an increase in teaching personal for 70000 places in order to decrease the child-to-carer ratio. In terms of indirect employment of the mothers the study presents 
2 scenarios: the pessimistic (optimistic) one assumes that $25 \%(50 \%)$ of the women whose children benefit from new childcare places will enter the labour market. Additional revenues from the direct and indirect employment created (income tax, social security contributions) and lower transfer payments outweigh additional running costs for wages, training, maintenance and financing within 5 years in both scenarios. Including the initial investment costs, the break-even point occurs 7 years after the start of the programme in the average scenario (37.5\% of mothers newly employed).

45. The use of childcare fees would help to cover the running costs of childcare facilities. At present, Austria exhibits the lowest childcare fees (as a share of average earnings) of all OECD countries. More cost-based pricing of services could further boost private supply. As in peer countries, tax breaks and rebates for low income families and targeted subsidies could be used to reduce net costs of childcare and reduce inequalities. Indeed, net childcare costs for sole parent families are actually lower in no less than 8 OECD countries notably due to means-tested benefits and rebates (Figure 12).

Figure 12. Net childcare costs for a sole-parent family with earnings of $50 \%$ of the average wage

Out-of-pocket childcare costs for a sole parent: full-time care at a typical childcare centre, 2012

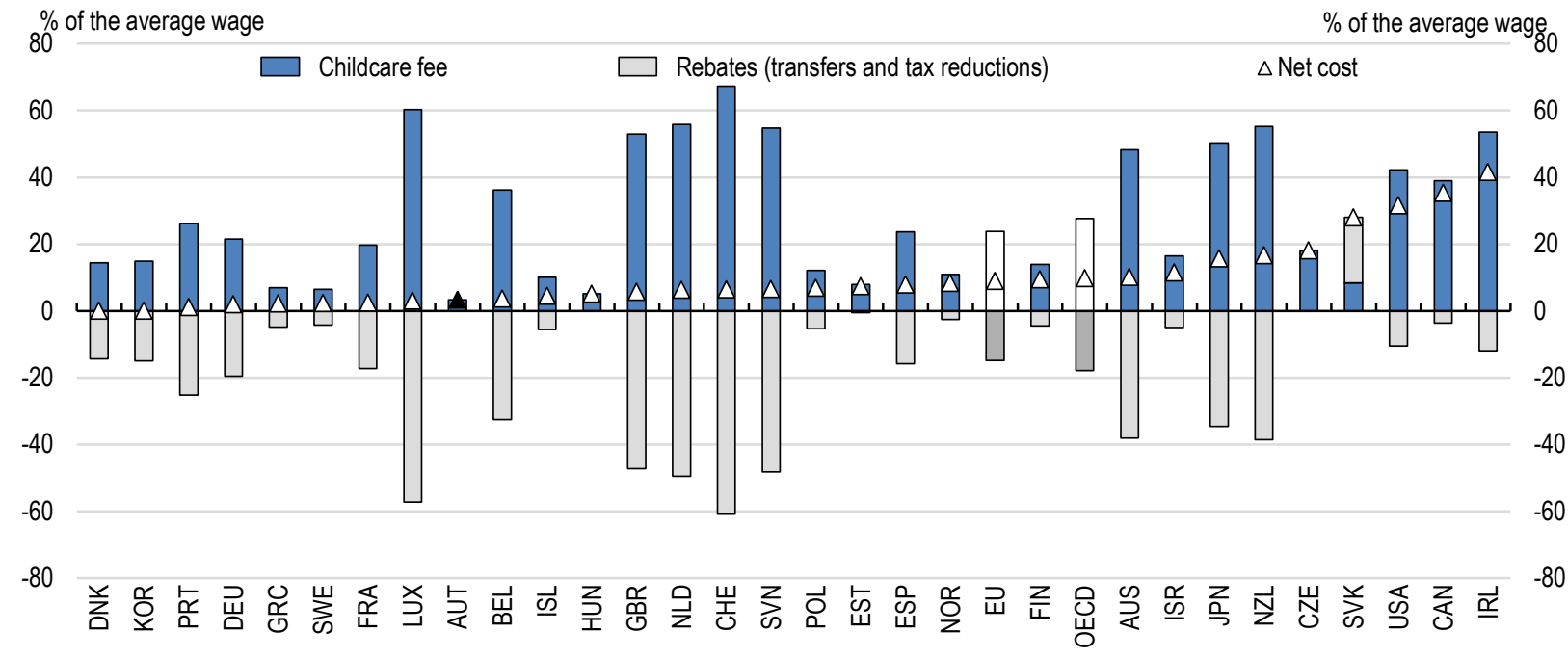

Note: Austria is represented by parameters for Vienna.

Source: OECD (2014), Family database (www.oecd.org/social/family/database.htm).

46. A national investment plan for childcare infrastructure could be linked to a legal entitlement for a place in formal childcare facilities for young children. Such a legal right has recently been introduced in Germany for 1 to 3 year olds and would substantially reduce regional inequalities with respect to the ability of combining work and family life. Investment in childcare infrastructure might further benefit from new regulations with respect to spending on social infrastructure. The European Economic and Social Committee (EESC) has proposed to exclude such expenditures from the EMU's fiscal rules for the calculation of government debt and public deficits.

47. The government could also encourage the installation of more corporate childcare facilities. According to a study conducted by the Austrian institute for families (ÖIF) in corporation with the University of Vienna (Kaindl, 2011), the share of corporate childcare facilities in the total supply is only $2 \%$ in Austria. Less than half of the existing facilities have received public support, mostly provided by the Länder, but nearly half of them declare that they would not have introduced the facility without public financial support. Administrative burdens for the grants seem to be very high and there are no clear criteria 
for the provision of public support neither at the federal nor at the regional level. The advantage of corporate childcare facilities is that opening hours can be better aligned to the working hours of employees and that commuting distances are reduced. Surveys results suggest that the availability of corporate reduces the duration of parental leave as it encourages parents to re-enter the workplace more swiftly. Indeed, enrolment rates for the 0-2 year olds largely exceed the ones observed in external day-care centres. More than $80 \%$ of the children enrolled in the surveyed corporate facilities entered before the age of 2 . Streamlining and making the eligibility criteria more transparent could increase take-up rates of public support. ${ }^{12}$

\section{Elderly care}

48. As in other OECD countries, Austria faces a strong rise in old-age dependency ratios driven by increasing longevity and declining fertility rates. The ratio of persons 65 or older over the working age population is expected to double by 2060 and reach 50\%. Additionally, Austria exhibits a rather high share of persons aged 75 years and older who report limitations in daily activities (OECD/European Union, 2013). Accordingly, ensuring and improving the quality and provision of long-term care (LTC) has become a major policy objective.

49. In Austria, nearly four fifth of the elderly are cared for in family environments, either in their families' home or in their own home under family surveillance (Gönenç et al., 2015). This is particularly relevant for the gender equality policy objective as the vast majority of working-age informal care-givers are women. Going forward, the ratio of caregiving cohorts (40-59 years) with respect to the population older than 70 (80) years will pass from 2.3 (6.0) in 2014 to 1.5 (3.7) in 2030 and 1.1 (2.1) in 2050. As a consequence, the demand for care places and other formal LTC services is additionally fuelled by a necessary shift from informal to formal care. Famira-Mühlberger and Firgo (2014) project that care expenditures will more than double between 2012 and 2030 with large discrepancies between the regions mainly driven by different starting conditions with respect to the provision of external care.

50. The Austrian LTC system encompasses universally provided cash benefits for persons in need of care on the one hand (Box 8), and publicly provided services and benefits in-kind on the other. Recent reforms have streamlined the process of providing LTC cash benefits. Until 2012, executive powers were at the Länder-level which led to considerable administrative costs and regional discrepancies. In 2012, all responsibility in granting the benefits has been transferred to the federal level, which reduced the numbers of decision makers from 300 to 5. This is likely to increase the transparency of the care benefit enforcement procedures and to ensure inter-regional equity among dependants. It also aligns financing and granting responsibilities which is bound to improve efficiency and financial sustainability.

12. Specific rules could be laid out to not penalise SME's with insufficient space (facilitating the set-up of a childcare facility for several surrounding firms, etc.). 


\section{Box 8. Long-term care cash benefits}

Long-term care benefits are non-means-tested benefits, awarded to dependants in need of care. Its amount depends on the hours of effective care need determined by a medical expert. ${ }^{13}$ Women claim long-term benefits significantly more often than men. In $2012,10.1 \%$ of the women and $7.8 \%$ of the men aged $61-80$ received long-term care benefits. For the age-group 81 years and above, take-up rates were $67.7 \%$ for women and $44.6 \%$ for men. LTC cash benefits are not linked to actual spending on care services and their amount is usually not sufficient to cover costs of formal long-term care services. As a result, a large part of long-term care is provided on an informal basis by family members. In $2013,59 \%$ of the claimants did not make use of any professional care or nursery service and were taken care of at home by relatives.

\section{Long-term care benefits}

\begin{tabular}{ccccc}
\hline $\begin{array}{c}\text { Care } \\
\text { category }\end{array}$ & $\begin{array}{c}\text { Monthly benefit } \\
\text { (Euros) }\end{array}$ & Care need in hours & $\begin{array}{c}\text { Number of } \\
\text { claimants }\end{array}$ & $\begin{array}{c}\text { Share of care } \\
\text { category } \\
\%\end{array}$ \\
\hline 1 & 154.20 & More than 65 hours & 104393 & 23 \\
2 & 284.30 & More than 95 hours & 130803 & 29 \\
3 & 442.90 & More than 120 hours & 78170 & 17 \\
4 & 664.30 & More than 160 hours & 63463 & 14 \\
5 & 902.30 & More than 180 hours ${ }^{1}$ & 46089 & 4 \\
6 & 1260.00 & More than 180 hours & 18806 & 2 \\
7 & 1655.80 & More than 180 hours ${ }^{3}$ & 9206 & \\
\hline & & & \\
1.Exceptional care requirements. & & \\
2.Permanent presence of caregiver is necessary due to unpredictable care needs. & \\
3.Serious disability impeding the use of hands and feet. No precise movements are possible. & \\
Source: Federal Ministry of Social Affairs. Numbers refer to 2013. &
\end{tabular}

51. Several measures provide support to caregiving family members of dependants. Employees who have to give up their job in order to provide care to relatives that are eligible for LTC of at least category 3 , are offered preferential terms for self-insurance or continued insurance under the statutory pension system for an unlimited period of time. Employers' and employees' contributions are paid by the state. Workers or employees who care for relatives are entitles to take unpaid care leave or to work part-time with prorated wage payments for a period between 1 and 3 months, renewable once. During the leave period, care-givers are entitled to care leave benefits that are essentially equal to replacement rates of the unemployment benefit scheme $(55 \%){ }^{14}$

52. Apart from LTC cash benefits, and care leave, the 24-hour care aid constitutes the third pillar of government support for home care. Financial support to care-taking persons amounts to EUR 550 (EUR 275) per month and employed (self-employed) caregiver for a maximum of EUR 1100 (EUR 550). Entitled are claimants of long-term care benefits of category 3 or beyond whose monthly net market income (excluding long-term care benefits and other transfers) does not exceed EUR $2500 .{ }^{15}$ To complement the provision of home care support, mobile care, day-care and in-patient services have recently gained importance in Austria. The institutionalisation of 24-hour has put an end to growing grey market where LTC cash benefits have been used to employ informal care-givers, mostly migrants, without

13. As of 2016, monthly benefits increase by $2 \%$.

14. In total, for the same family member in need of care, the number of monthly care leave benefits cannot exceed 12 months to be shared among care-giving family members unless the leave is transformed in hospice leave for the purpose of nursing a dying close family member or a seriously ill child.

15. This threshold rises by EUR 400 for each dependant relative and by EUR 600 for each dependant relative with disabilities. 
appropriate monitoring and qualification management. Their work is now legally framed which ensures the quality of the care and provides social insurance coverage to the caregivers. ${ }^{16}$

53. In contrast to the universally provided LTC cash benefits, LTC services are not free of charge. Fees are cost-based and the dependant is liable with her personal disposable income including cash benefits and with assets that may be monetised. ${ }^{17}$ Only once these resources are exhausted, costs get financed by the Länder via the Social Assistance and the Guaranteed Minimum Income Schemes. Provision and monitoring of institutional care is the sole responsibility of the federal provinces in Austria which means that there are no common quality standard or outcome documentations. This makes it difficult to compare service provision across regions, but large differences occur in terms of beneficiaries, gross spending and receipts (Figure 13), and minimum quality requirements. ${ }^{18}$ The Federation of Care Homes and the Federal Ministry of Labour, Social Affairs and Consumer Protection engaged in a voluntary National Quality Certificate (NQZ) that can be obtained by care homes, which have successfully implemented an accredited quality management system. Since 2013, an independent NQZ organisation was established to administer and further develop the certification procedure. Such certificates foster competition between the regions, ensure common standards across Länder and are an encouraging example for achieving independent monitoring of legislation that is delegated to subnational government bodies in a decentralised system.

Figure 13. Provision of long-term care services by Länder

In 2013, for population aged 65 and more
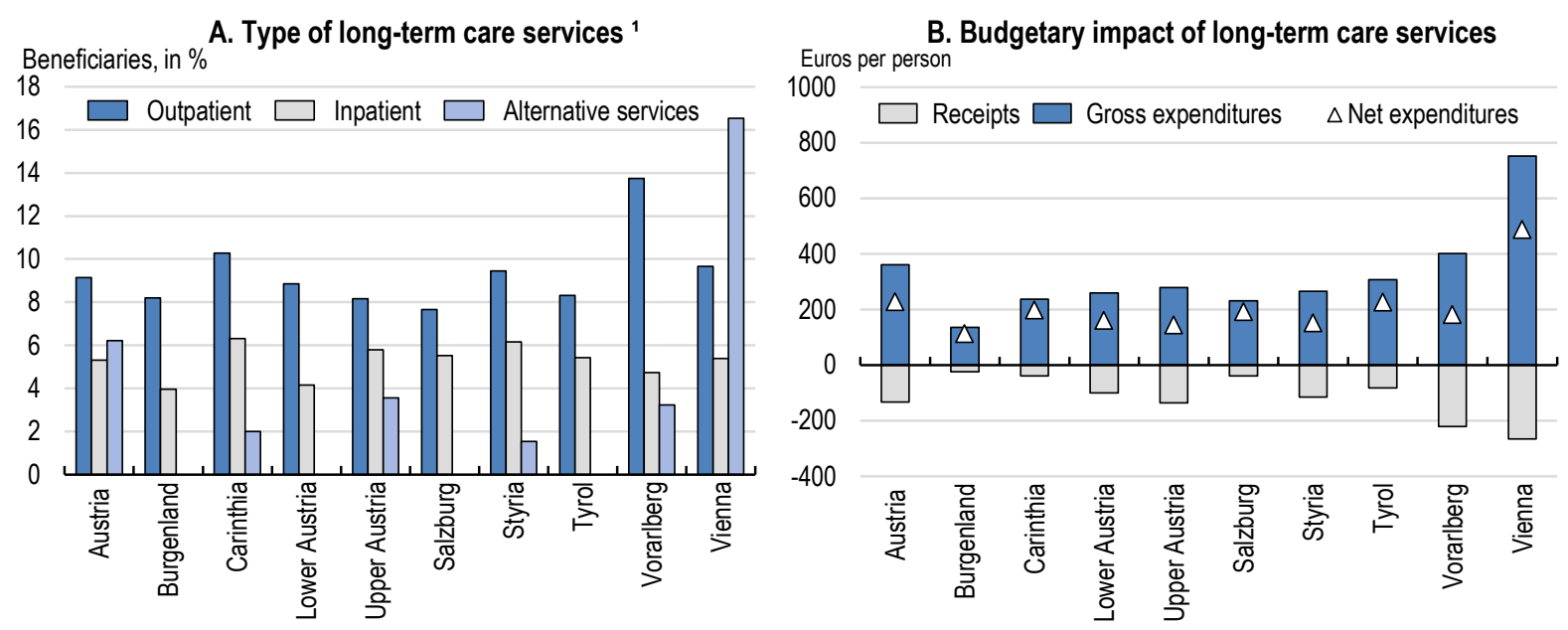

1. In-patient services include semi-in-patient services. Alternative services comprise short-term care, alternative living facilities and case and care management.

Source: Statistik Austria.

16. Since 2009, caregivers need to complete dedicated training or, alternatively, they need to prove that they have cared for the caretaker in satisfactory manner for at least 6 months.

17. In addition, the so-called "Familienregress" obliged relatives to co-finance long-term care costs of family members with their respective incomes and assets. This scheme has been abolished over time by all Länder. Styria re-introduced the co-payments of children (for their parents) and parents (for their children) in 2011 before abolishing it again in July 2014.

18. For instance, minimum room sizes vary substantially across regions from $24 \mathrm{~m}^{2}$ in Vorarlberg $13.48 \mathrm{~m}^{2}$ in Salzburg. Similar differences can be observed for staff-to-patient ratios. 
54. The number of beds in residential care facilities is lower than the OECD average and much lower than in many countries (Figure 14). This reflects the substantial bias towards home care and a general praise for satisfactory innovations, in particular, alternative living facilities and case and care management services, although the provision of such services shows substantial regional differences (Figure 13). Indeed, only in Vienna the coverage of such innovative solutions is currently sufficiently to substitute or complement home care provided by relatives where formal residential care is not available or not affordable.

Figure 14. Number of beds in residential long-term care facilities 2012, per 1000 population aged 65 years old and over

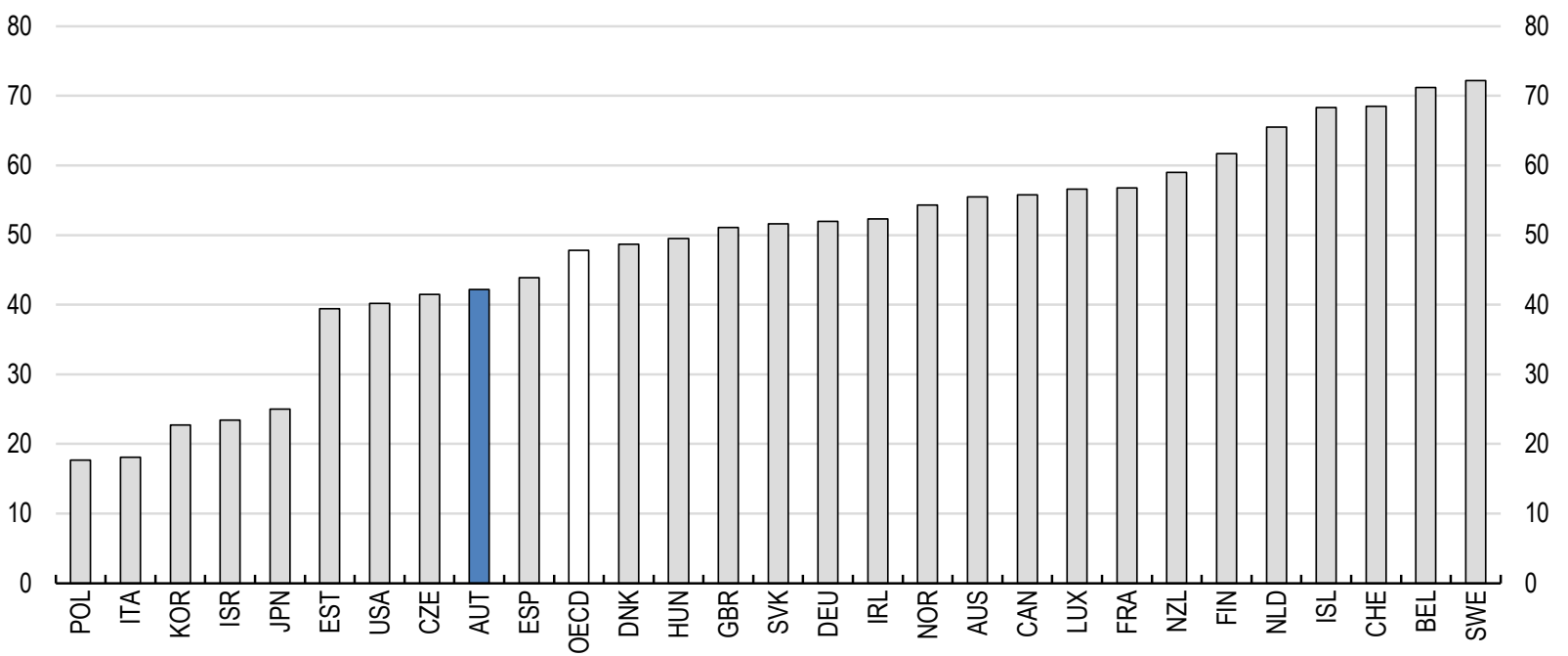

Source: OECD Health Statistics database.

55. Going forward, the current care arrangements face several challenges. First, due to an ageing society fewer family members will be available per dependant, which will put pressure on the sustainability of home-care provision by relatives. Second, convergence towards more gender-equality also implies that elderly care, similar to childhood care, needs to gradually shift towards external care provision. This could require investment in residential facilities and spending on subsidies to mobile care, in-patient care providers or other innovative solutions (alternative living facilities, case and care management, etc.). This would be partly self-financed by higher employment rates of women who formerly partly or fully withdrew from the labour market to provide care. The vast majority of elderly related spending is currently provided as a lump-sum cash transfer. With the transition from informal towards formal elderly care, spending efficiency may benefit from a higher extent of targeted and meanstested transfers.

\section{Encourage more flexible workplace practices}

\section{Fostering family-friendly workplaces}

56. Empirical evidence suggests that there are important benefits from a more gender-equal worker structure (Weber and Zulehner, 2014). A family-friendly work environment fosters the motivation and loyalty of employees and makes firms more attractive for skilled young workers with realised or potential family duties. International experience suggests that, in the global open economy, such work conditions are also a major precondition to attract high-level international workers. At the same time, these environments 
should be designed without jeopardising the competitiveness of enterprises. Mandatory legislation and negotiated collective agreements and voluntary enterprise initiatives will need to be used complementarily. It should be recognised, however, that for small and medium sized enterprises the implementation of more flexible workplaces is more challenging which calls for targeted support policies.

\section{Box 9. Work and Family audit}

Since 1998, the Austrian government subsidises and supports "work and family audits" that assess the compatibility of a company's work environment with family related needs. Through discussions with management and employees, the auditor first identifies current setups and needs and then defines targets based on well-performing peer enterprises. A corresponding company plan with dedicated goals and defined time spans is established. Relevant indicators are working hour flexibility, organisation and place of work, information and communication policy, management culture, personnel development, remuneration aspects, services for families, parental leave characteristics and health promoting measures. All Austria-based firms with a minimum of 5 employees are eligible. Auditing and expert fees are partly subsidised by the Austrian government (between 2000 and 5000 Euros depending on the size of the company). Every 3 years, and subject to validated improvements, the Austrian Federal Ministry for Families and Youth awards a certificate that attests the quality of a family-friendly work environment. Annual reports and periodical re-assessments ensure the sustainability of the auditing and certifying process. A special "compact" audit was recently developed for the needs and challenges of small firms employing 5 to 50 employees.

In addition, the "university and family audit" is geared to requirements of family-friendliness in tertiary education and the "work and family for nursing and care institutions audit" was developed to deal with the challenges faced by health care institutions. The "family-friendly community audit" addresses villages, small towns and cities aiming at identifying and enhancing existing family-friendly measures.

57. The work and family audit organised by the Austrian government (Box 9) enables employers to benefit from external assessment and tailor-made solutions to improve the work environment for employees with family duties. The involvement of the Federal Ministry of, Families and Youth, that provides merits-based certificates, fosters visibility and significance of the auditing and evaluation process. It also allows firms to benefit from best practices and experiences of other firms. The audit further raises awareness and sensibility of the gender issue and triggers competition between the firms so as to converge to high standards in terms of reconcilability of work and family life.

58. Well-designed, professionally attractive up-skilling programmes draw the interest of both genders. A Ministry of Labour scheme helping middle-age women to change professions has been oversubscribed. A "Committee on New Skills" elaborates, in co-operation with social partners, new curricula for such programmes. These innovations may help overcome the further entrenchment of skill biases in post-formal adult education.

59. Other initiatives, such as the INQA (Initiative New Quality of Work) in Germany, could serve as a benchmark for Austrian businesses. The project targets SME's and brings together social partners and employers. It focusses on communicating and developing best practices in the fields of personnel management (e.g. life-cycle orientation), equal opportunities and diversity (e.g. heterogeneous teams), health (e.g. accounting for stress) and knowledge and competencies (e.g. internal share of acquired knowledge).

60. A growing desire to better align career aspirations with family prospects also calls for innovative working time models. A recent Freizeitoption (leisure option, Box 10) has been implemented in some collective agreements. Subject to approvals at the plant and the individual level, it enables the employee to exchange the annual pay increase against a reduction in working time. According to Soder (2014), 10\% of the concerned employees in the electronic and electrical engineering industry have exercised the option for 2014 subsequent to the collective agreement in 2013. The leisure option can only be used once and reduces the working time on a permanent basis. More flexible options that allow both sides to adjust working time 
dynamically, by taking competitiveness and order-book considerations on the one hand and changing family duties over the life cycle on the other hand into account, could be envisaged. It would make fulltime employment more conceivable for mothers and it allows fathers to take up a bigger share of family duties.

\section{Box 10. "Die Freizeitoption" - a recent instrument to rebalance family and work life}

In spring 2013, as part of the collective agreement in the electrical and electronics industry, a new instrument to facilitate the implementation of flexible working was introduced. The Freizeitoption (leisure option) responded to a growing desire of employees to reduce working time to achieve a better balance between family, leisure and work. It allowed the employee to trade the agreed pay increase of $3 \%$ against a reduction in annual working time of 60 hours. The option was not a legal entitlement and required prior agreements at the firm and individual level. Employees whose income would fall below the minimum wage in case of exercising the leisure option were not eligible. According to survey results, $73 \%$ of the companies covered by the collective agreement have refused to implement the option as part of their company agreements (Soder, 2014). In more than half of the cases the refusal was due to a rejection from the executive board mainly on the grounds of uncertainty regarding the implementation in general and the accounting procedures in particular. Within the companies that ultimately offered the option, roughly $10 \%$ of the workers and employees have reached an agreement with their employer and exercised the leisure option. While the steel, metallurgic and mining industries as well as the automotive industries have followed the example by introducing the leisure option in their collective agreements, others have refused to do so. The machine and metal goods industry, for instance, has rejected the implementation of the Freizeitoption amid fears over impaired cost competitiveness and reduced flexibility in responding to order fluctuations and uncertainty.

\section{Improving gender-equality in corporate and public decision making}

61. The share of women on boards or in executive management positions is substantially below the European Union average (Gönenç et al., 2015). The government has launched the "Women are top" initiative that is co-financed by the European Commission. The initiative has two legs. The first focusses on nomination processes for the assignment of board members. The aim is to simulate good and current practices in order to understand and reveal gender-stereotypical patters in assignment processes. The second leg will deliver a catalogue of measures that have been proven to foster gender equality in management positions in selected companies. According to first results, the measures will concentrate on areas such as working time, mobility, recruitment processes and life-phase sensitive career tracks. In line with the leadership-programme "Zukunft.Frauen", another initiative of the government, eight training courses with 176 participants have already been completed - the ninth is starting in autumn 2015. A key element of this initiative is the establishment of a publicly accessible data base for female supervisory boards, where currently more than 410 women are registered.

62. In political decision making, the situation is slightly different. Market forces are not the main drivers and a certain degree of pro-active outcome equalisation is needed to correct the underrepresentation of women in public institutions that are meant to mirror and represent the society. In Austria, self-imposed or voluntary quotas have been introduced in 2 out of 6 political parties present in parliament. As of 2014, 30.6\% of the Members of Parliament were women. Similar shares are observed for female participation in government (4 out 14 ministers and chancellor). In 2011, the government decided to impose gender quotas for the state delegates sent to boards of the 55 companies in which the state holds a majority of the shares. The initial target is $25 \%$ in 2013 and the quota will be raised to $35 \%$ by 2018. According to a report of the Ministry for Science, Research and Economy and the Ministry of Education and Women's affairs, the 2018 target has already been reached in 2014 as the share of women of state delegates in these boards has reached 36\% (after 16\% in 2008 and 26\% in 2011).

63. In public services, following the introduction of the Federal Equality Treatment Act, quotas for female employment have progressively been raised to $50 \%$. These targets are far from met as the overall 
share of women in public service positions remains broadly constant at around 40\% since 1999 (Austrian Federal Ministry for Education and Women's affairs, 2014). At high level positions, the women's share, though largely below the 50\% target, has constantly increased and reached 33.7\% in 2013 up from 18.2\% in 1999 and 27.2\% in 2005. Similar quotas exist in Public Broadcasting (ORF) and universities.

\section{Streamline family policies across regions and levels of government}

64. Differences in legislation and implementation across Länder lead to weak synergies and create inefficiencies and inequalities. On the other hand, they may be a source of emulation and innovation. The challenge is to make the Austrian federal system a support and not an obstacle to gender mainstreaming efforts. Executive, spending and financing authorities are often associated with different levels of the administration which leads to inefficient spending. ${ }^{19}$ Most envisaged reforms related to the supply of childcare services may require redistribution and clear division of competencies between the State, the Länder and the local governments. In particular the consolidation of competencies with respect to schools, pre-schools and day-care services has been identified as a necessary condition to make progress (Pitlik et al., 2010).

65. There is also a need for more coordination at the federal level to ensure a coherent and sustainable child development policy across the country. ${ }^{20}$ On the financing side, arrangements should be optimised on the basis of past domestic experience and international good practices. On the executive side, for each policy target, and depending on constitutional constraints, policy makers have to decide whether a centralised or decentralised implementation is most effective. Reforms should aim at extending autonomy of schools and care institutions combined with superordinate monitoring (state monitors Länder, Länder monitor communities, and communities monitor schools). A working group entitled "Verwaltung neu" ("Administration new") under the umbrella of the Court of Auditors, the IHS, WIFO and the KDZ have worked out proposals for a comprehensive reform of the federal administration.

66. In terms of innovations with regard to care services, there may be a case for decentralisation. Successful projects could be implemented and transferred to other regions. There may also be scope for a differentiated approach that takes regional characteristics into account. Regional competition could also trigger convergence towards best practices in terms of gender mainstreaming and reduce the substantial inter-regional disparities currently observed (Bock-Schappelwein, 2013).

\section{Recommendations to promote gender equality}

\section{Key recommendations}

- Spur investment in high quality childcare facilities. Enhance the availability of full-day schools and care centres. Consider introducing legal entitlements for these services.

- Reduce the implicit taxation of transition from marginal and part-time to full-time employment and replace the sole-earner tax deduction by targeted transfers to families in need.

- Transform childcare allowance and parental leave schemes into a unique childcare account that allows parents to allocate subsidised absence from work flexibly over time. Reserve a sizeable part of this account, at least $33 \%$, for the exclusive use of fathers.

- Raise awareness by publicising more information on innovations in study area choices of schoolgirls

19. For instance, local governments pay the total wage bill for teachers, but are completely reimbursed by the federal state. In such a situation, local government have no incentive to act in a cost-benefit efficient manner.

20. The implementation of standardised accounting practices, as currently announced by the Finance minister, is a necessary condition for such progress 


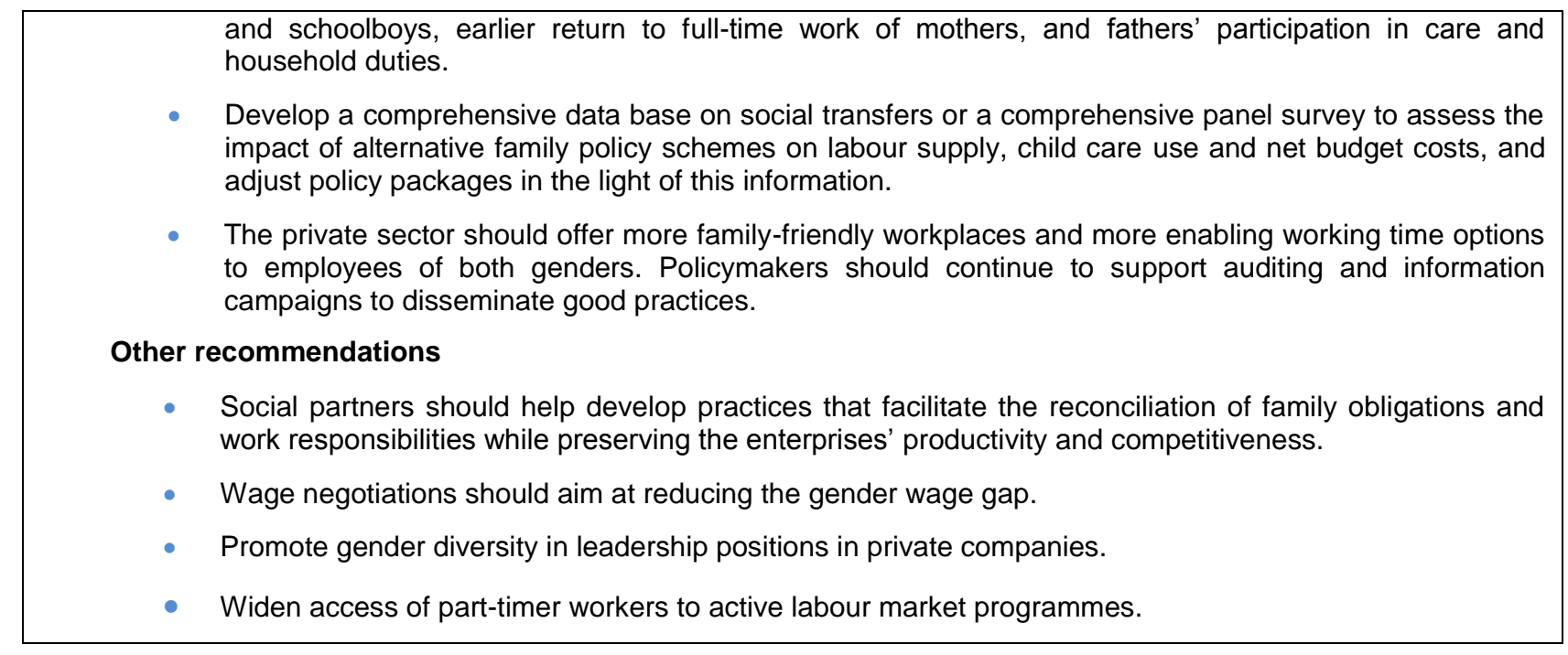

\section{BIBLIOGRAPHY}

Adema, W. (2012), "Setting the Scene: The Mix of Family Policy Objectives and Packages Across the OECD. Children and Youth Services Review, Vol. 34, No. 3, pp. 487-498.

Adema, W., N. Ali et O. Thévenon (2014), "Changes in Family Policies and Outcomes: Is there Convergence?", OECD Social, Employment and Migration Working Papers, No. 157, OECD Publishing.

Austrian Federal Chamber of Labour (2013), "Social Investment Growth, Employment and Financial Sustainability: Economic and Fiscal Effects of Improving Childcare in Austria", AK Position Paper.

Austrian Federal Ministry for Education and Women's affairs (2014), “10. Gleichbehandlungsbericht des Bundes 2014", Vienna.

Austrian Institute for Youth Research (2004), “Österreichischer Hintergrundbericht zur OECDLänderprüfung", Starting Strong.

Barnay, T. (2014), "Health, Work and Working Conditions: A Review of the European Economic Literature", OECD Economics Department Working Papers, No. 1148, OECD Publishing.

Buber-Ennser I., N. Neuwirth and M. Testa (2014), Families in Austria 2009-2013: Descriptive findings on partnerships, fertility intentions, childbearing and childrearing, Vienna Institute of Demography, Vienna.

de Boer, H. W., Jongen, E. and J. Kabátek (2014), “The Effectiveness of Fiscal Stimuli for Working Parents”, CPB Netherlands Bureau for Economic Policy Analysis, CPB Discussion Paper, No. 286.

Bock-Schappelwein, J. (2013), "Genderindex. Arbeitsmarktlage und Lebenssituation von Frauen und Männern auf regionaler Ebene in Österreich", Study commissioned by Austrian Federal Ministry of Agriculture, Forestry, Environment and Water Management.

Famira-Mühlberger, U. and M. Firgo (2014), "Die Entwicklung des öffentlichen Aufwandes für Pflegedienstleistungen. Projektion für die österreichischen Bundesländer". WIFO-Monatsberichte, 2014, Vol. 87, No. 9, pp. 643-652. 
Förster, M. F. and G. Verbist (2012), "Money or Kindergarten? Distributive Effects of Cash Versus InKind Family Transfers for Young Children", OECD Social, Employment and Migration Working Papers, No. 135, OECD Publishing.

Gönenç, Rauf, B. Guerard, I. Hassler and A.Wörgötter (2015), "Austria's Separate Gender Roles Model was Popular in the Past, but is Becoming a Constraint for Comprehensive Wellbeing," OECD Economics Department Working Papers, No. 1272, OECD Publishing, Paris.

Heckman, J. (2006), "Skill Formation and the Economics of Investing in Disadvantaged Children", Science, Vol. 312, No. 5782, pp. 1900-1902.

Holzer, H. J. and D. Neumark (2000), “What does affirmative action do?”, Industrial \& Labor Relations Review, Vol. 53, No. 2, pp. 240-271.

Huerta, M., et al. (2011), "Early Maternal Employment and Child Development in Five OECD Countries", OECD Social, Employment and Migration Working Papers, No. 118, OECD Publishing, Paris.

Huerta, M., et al. (2013), "Fathers' Leave, Fathers' Involvement and Child Development: Are They Related? Evidence from Four OECD Countries", OECD Social, Employment and Migration Working Papers, No. 140, OECD Publishing.

Johansson, Å., et al. (2013), "Long-Term Growth Scenarios”, OECD Economics Department Working Papers, No. 1000, OECD Publishing, Paris.

Kaindl, M. (2011), "Betriebliche Kinderbetreuung in Österreich Angebotsstruktur sowie Motive und Erfahrungen der Unternehmen im Bereich der betrieblichen Kinderbetreuung", Austrian Institute for Families, Working Paper No. 75.

Klüsener, S., K. Neels, and M. Kreyenfeld (2013), "Family Policies and the Western European Fertility Divide: Insights from a Natural Experiment in Belgium", Population and Development Review, Vol. 39, No. 4, pp. 587-610.

de Laat, J., and A. Sevilla-Sanz (2011), “The Fertility and Women's Labor Force Participation Puzzle in OECD Countries: The Role of Men's Home Production”, Feminist Economics, Vol. 17, No. 2, pp. 87-119.

Lassnigg, L., A. Kulhanek and P. Wejwar (2014), "Quantitative Information about sex and gender issues in the Austrian National Education Report - overview and assessment", 8th European Conference on Gender Equality in Higher Education, Vienna University of Technology, Vienna, September 3-5, 2014.

Lesthaeghe, R. and I. Permanyer (2014), "European Sub-Replacement Fertility: Trapped or Recovering?", Population Studies Center Research Report, No. 14-822.

Moss, P. (Ed.). (2012), "International review of leave policies and related research 2012”, International Network on Leave Policies and Related Research.

Müllbacher, S., H. Hofer and G. Titelbach (2014), "Verteilungswirkung und Anreizstruktur des Österreichischen Steuer- und Transfer-Systems", Institute for Advanced Studies, Vienna. 
Musset, P., et al. (2013), A Skills beyond School Review of Austria, OECD Reviews of Vocational Education and Training, OECD Publishing.

Nordenmark, M. (2014), "Disagreement about Division of Household Labour and Experiences of WorkFamily Conflict in Different Gender Regimes", GÉNEROS - Multidisciplinary Journal of Gender Studies, Vol. 2, No. 3, pp 205-232.

Niederle, M., C. Segal and L. Vesterlund (2013), "How costly is diversity? Affirmative action in light of gender differences in competitiveness", Management Science, Vol. 59, No. 1, pp. 1-16.

OECD (2011a), The Future of Families to 2030, OECD Publishing.

OECD (2011b), "The Impact of Caring on Family Carers", in F. Colombo, et al. , Help Wanted?:

Providing and Paying for Long-Term Care, OECD Publishing.

OECD (2011c), Doing Better for Families, OECD Publishing.

OECD (2011d), Starting Strong III: A Quality Toolbox for Early Childhood Education and Care, OECD Publishing.

OECD (2013a), "Recommendation of the Council on Gender Equality in Education, Employment and Entrepreneurship", 29 May.

OECD (2013b), OECD Skills Outlook 2013: First Results from the Survey of Adult Skills, OECD Publishing.

OECD (2014a), Education at a Glance 2014: OECD Indicators, OECD Publishing.

OECD (2014b), Women, Government and Policy Making in OECD Countries: Fostering Diversity for Inclusive Growth, OECD Publishing.

OECD/European Union (2013), A Good Life in Old Age?: Monitoring and Improving Quality in Long-term Care, OECD Health Policy Studies, OECD Publishing.

Neyer, G. (2013), "Welfare States, Family Policies, and Fertility in Europe", In The demography of Europe (pp. 29-53), Springer Netherlands.

Pitlik, H. et al. (2010), Verwaltungsmodernisierung als Voraussetzung für nachhaltige Effizienzgewinne im öffentlichen Sektor, Wifo.

Phillips, A. (2006), “'Really’ Equal: Opportunities and Autonomy”, Journal of political philosophy, Vol. 14, No. 1, pp. 18-32.

Riesenfelder, A. (2013), "Wiedereinstiegsmonitoring Ein Überblick über die Ergebnisse der Kohorten 2006 bis 2010 in Österreich und in der Bundeshauptstadt Wien.”, L\&R Social Research.

Robeyns, I. (2006), "The Capability Approach in Practice”, Journal of Political Philosophy, Vol. 14, No. 3, pp. 351-376.

Schneebaum, A., B. Rumplmaier and W. Altzinger (2013), "Gender and Migration Background in Intergenerational Educational Mobility", Vienna University of Economics and Business Working Paper Series, No. 156. 
Schratzenstaller, M. (2014), "Gender Impact Assessment in Austria”, European Union Programme for Employment and Social Solidarity - PROGRESS (2007-2013).

Seguino, S. (2013), "Toward gender justice: Confronting Stratification and Unequal Power." GÉNEROSMultidisciplinary Journal of Gender Studies, Vol. 2, No. 1, pp. 1-36.

Sen, Amartya K. (1993), "Capability and Well-being”, in Martha C. Nussbaum and Amartya K. Sen (eds), The Quality of Life, Oxford: Clarendon Press, pp. 30-53.

Sobotka, T., and M. R. Testa (2008), "Attitudes and intentions toward childlessness in Europe”, In People, Population Change and Policies (pp. 177-211). Springer Netherlands.

Soder, M. (2014), “Die Freizeitoption in Kollektivverträgen”, Materialien zu Wirtschaft und Gesellschaft, No. 127, Austrian Chamber of Labour, Vienna.

van Staveren, I. (2014), “The Lehman Sisters Hypothesis”, Cambridge Journal of Economics, Vol. 38, No. 5, pp. 995-1014.

Sullivan, O., F. C. Billari and E. Altintas (2014), "Fathers' Changing Contributions to Child Care and Domestic Work in Very Low-Fertility Countries: The Effect of Education", Journal of Family Issues, Vol. 35, No. 8, pp. 1048-1065.

Thévenon, O. (2013), "Drivers of Female Labour Force Participation in the OECD", OECD Social, Employment and Migration Working Papers, No. 145, OECD Publishing, Paris.

Weber, A., and C. Zulehner (2014), "Competition and Gender Prejudice: Are Discriminatory Employers Doomed to Fail?", Journal of the European Economic Association, Vol. 12, No. 2, pp. 492-521. 